\title{
NORMA LÍNGUÍSTICA E ORALIDADE FINGIDA NA TRADUÇÃO DE PERSÉPOLIS
}

\author{
Language Standard and and Pretend Orality in The Translation of \\ Persepolis
}

\author{
Ana Cláudia Vieira BRAGA \\ Doutoranda, Universidade de Brasília \\ anaclaudiaunb2012@gmail.com \\ Marcos Araújo BAGNO \\ Universidade de Brasília \\ bagno.marcos@gmail.com
}

RESUMO: O romance gráfico Persépolis, de Marjane Satrapi, traduzido do francês para o português brasileiro por Paulo Werneck, é o corpus dessa pesquisa. Nesse artigo apresentamos a análise das representações de normas presentes no romance gráfico por meio de exemplos de oralidade fingida com vistas à análise linguística das normas e dos fenômenos variáveis que incidiram sobre o texto final traduzido, dando ênfase a alguns traços gramaticais do português brasileiro: demonstrativos esseleste, formas do imperativo, relações pronominais você/te, emprego dos verbos ter e haver, emprego de nós e a gente evidenciando as representações de normas linguísticas do português brasileiro que estão presentes no texto final traduzido de Persépolis. PALAVRAS-CHAVE: Quadrinhos; Tradução; Oralidade Fingida.

\begin{abstract}
The graphic novel Persepolis, by Marjane Satrapi, translated from French into Brazilian Portuguese by Paulo Werneck, is the corpus of this research. In this article we present the analysis of the representations of norms present in the Grafic Novel by means of examples of pretended orality with a view to the linguistic analysis the norms that focused on the translated final text, emphasizing some grammatical features present in Brazilian Portuguese: demonstratives esse/este, imperative forms, pronominal relations você / te, employment of verbs ter and haver and employment of nós/a gente. We also present which representations of Brazilian Portuguese language norms are present in the final translated text of Persepolis. KEYWORDS: Comics; Translation; Pretended Orality.
\end{abstract}




\section{INTRODUÇÃO}

É fácil, desde o primeiro contato, constatar que as histórias em quadrinhos (HQ) são um gênero de texto que requer uma leitura peculiar, visto que a união da imagem com o texto escrito amplia o universo de percepção do leitor. Diante da voz do texto escrito e da imagem, como realizar a tradução de uma história em quadrinhos? De certa forma, há uma ampliação dos recursos que serão aplicados na tradução: o autor utilizou a imagem que deve ser considerada pelo tradutor como chave de leitura. A premissa principal dessa pesquisa é de que as normas linguísticas incidentes no texto, por meio das escolhas do tradutor e também dos agentes normatizantes, assim como os traços de oralidade fingida, são fatores que influenciam no texto final traduzido e publicado.

\section{CADA UM EM SEU QUADRADO}

A partir dos elementos presentes na linguagem dos quadrinhos, o trabalho do tradutor dessas histórias não se restringe ao texto escrito, é preciso levar em conta outros desafios que vão desde uma linguagem icônica até as várias normas linguísticas que incidem no texto.

No gênero quadrinhos, os balões expressam a fala de cada personagem, e os autores usam os recursos gráficos para expressar a oralidade na escrita, o que leva o pesquisador (e, por conseguinte, o tradutor) a rever os conceitos de língua falada e língua escrita bem como suas inter-relações. Nas Histórias em Quadrinhos (daqui em diante HQ) toda representação escrita de usos supostamente orais será sempre um fingimento, impossível de escapar do hibridismo que caracteriza todo e qualquer uso da língua. O texto traduzido de HQ, para ser publicado, teve de passar por diversas etapas de normatização. Em geral, as escolhas do tradutor buscam corresponder ao gênero do texto, ao público alvo e às normas editoriais impostas pelos agentes normatizantes. A relação entre fala e escrita é muito estreita e a linguagem dos quadrinhos oferece uma característica essencial a mais: a oralidade fingida - conceito que explicitaremos mais adiante.

Sendo assim, o uso abundante de diálogos tem uma estreita relação com a oralidade fingida e as normas que incidem sobre o texto traduzido. A oralidade fingida influencia na forma de apresentação dos diálogos que precisam parecer o mais espontâneo possível. As normas da língua falada espontânea incidem sobre o texto dos diálogos que são representados pela língua escrita. Por fim, o texto do tradutor passa por agentes normatizantes antes da publicação que também superpõem ao conjunto suas normas 
tornando o texto final um exemplo híbrido de texto normatizado.

\title{
LINGUAGEM? QUE LINGUAGEM?
}

Para a tradução dos quadrinhos, Guerini (2013) destaca as características desse gênero cuja compreensão passa tanto pela linguagem verbal como pela linguagem visual, as quais, como sistemas semióticos, trabalham conjuntamente na produção dos sentidos. Faremos, então, um direcionamento terminológico sobre qual conceito de linguagem será usado na determinação de uma linguagem dos quadrinhos. A linguagem é de domínio individual e de domínio social, ela não se classifica unicamente em uma categoria dos fatos humanos, dificultando a definição de sua unidade. em cada texto está um sistema linguístico. como produto individual, cada texto é único e singular, e é escrito com uma intenção específica.

Eisner (1995) explica o conceito de quadrinhos como arte sequencial e trata das temáticas implícitas no universo artístico daqueles que trabalham com a linguagem especializada das HQ:

\begin{abstract}
A arte sequencial, particularmente como é aplicada às histórias em quadrinhos, destina-se essencialmente à reprodução. Portanto, devem visar quase simultaneamente à estética e às técnicas. Há poucas oportunidades para se improvisar nesta disciplina. A arte sequencial, especialmente nas histórias em quadrinhos, é uma habilidade estudada, que pode ser aprendida, que se baseia no emprego imaginativo do conhecimento da ciência e da linguagem, assim como da habilidade de retratar ou caricaturar e de manejar as ferramentas do desenho (EISNER, 1995, p.144).
\end{abstract}

As situações comunicativas em que as linguagens especializadas estão inseridas também cabem no universo de produção das HQ. Em geral quem procura informações mais específicas sobre a produção das HQ é um público que pretende aprender mais sobre a nona arte e tem um interesse explícito em suas técnicas e estruturas peculiares.

\section{Linguagem dos quadrinhos e a tradução: olhos de ler e ver}

As HQ são um suporte semiótico que proporciona uma leitura própria, na medida em que sua estrutura ressignifica a noção tradicional de texto, pois inclui em seu conceito não só a linguagem verbal mas também a visual.Sendo assim, a tradução de HQ também apresenta aspectos particulares a serem considerados. 
Se para o leitor comum, aquele que faz das HQ um meio de entretenimento ou de leitura preferida e tem como acesso a esta mídia a tira diária do jornal e da revista, é preciso exercer sobre a leitura da arte sequencial habilidades interpretativas, visuais e verbais, atribuídas principalmente pelo código único entre texto e imagem (EISNER, 1999, p.8), para o tradutor de HQ, as habilidades necessárias estão contidas principalmente na consideração de que a linguagem verbal e a linguagem visual são indissociáveis e formam uma unidade a ser considerada na tradução dos balões, que são os objetos da tradução nos quadrinhos.

Para uma compreensão da linguagem das HQ, Cirne (2000) caracteriza a mídia dos quadrinhos por meio de seus elementos semióticos, fazendo uma ponte entre a estética e a semiótica, disciplinas que, embora representem campos distintos, colaboram entre si na consolidação da linguagem das HQ como uma nova estética:

A rigor, a estética e a semiótica são campos distintos, mas ousemos pensar suas problematizações. Qualquer nova perspectiva estética, inclusive, só existe na medida em que uma conquista semiótica, experimental ou não, se consolida formalmente enquanto signo capaz de investir, do social ao cultural, na aventura do imaginário: a descoberta de novos caminhos significantes, como no dadaísmo, como na antropofagia, como no neoconcretismo. Como no poema/processo (CIRNE, 2000, p. 26).

Há também a caracterização imagética, na maioria dos textos em quadrinhos, da personalidade das personagens e, em alguns casos, da linguagem do gênero cômico/ humorístico, jogo de palavras, expressões idiomáticas, gírias, ironia, dentre outras que exigem do tradutor uma sensibilidade para a seleção de recursos com a finalidade de utilizar adequadamente as imagens na realização de seu texto final.

Se acrescentarmos a necessidade do conhecimento da linguagem especializada das HQ pelo tradutor, a tradução da arte sequencial se torna ainda mais peculiar, pois as sugestões imagéticas e a narração dos textos em quadrinhos precisam ser consideradas como um discurso especializado.

Pode ser simples a ideia de que o tradutor só traduz o texto dos balões e seus cartuchos e, porque não traduz as imagens, essas são irrelevantes no processo tradutório. No entanto, a escolha do tradutor ao traduzir um balão sempre estará associada às imagens do quadro e à estrutura narrativa que configuram a peculiaridade da linguagem das HQ.

Para Meschonnic (2010), a tradução de textos é uma tradução de discurso e não de língua, assinala ainda que "não se traduz mais a língua, ou, então, desconhece-se o 
discurso e a escritura. É o discurso, e a escritura, que é preciso traduzir"(2010, p. 20).

Considerando que a unidade da linguagem, para Meschonnic, não se resume só à unidade da palavra, a unidade passa a ser o discurso, todo o sistema do discurso (idem, p. 31), o que se traduz é discurso. A partir dessa afirmação a linguagem dos quadrinhos, que tem um discurso próprio, precisa ser bem conhecida para ser traduzida.

Os quadrinhos se revelam como uma linguagem específica que tem não só uma língua, mas também um discurso específico. Ao traduzir um balão, o tradutor precisa conhecer as características do discurso quadrinhístico e a partir deste conhecimento estruturar suas escolhas, sempre respeitando a indissociabilidade entre o verbal e o não verbal.

Vejamos então, para ilustrar, a importância da escolha do texto relacionado à imagem em uma tira da prancha Love Story do romance gráfico Persépolis de Satrapi (2011):

Tira 01: em francês
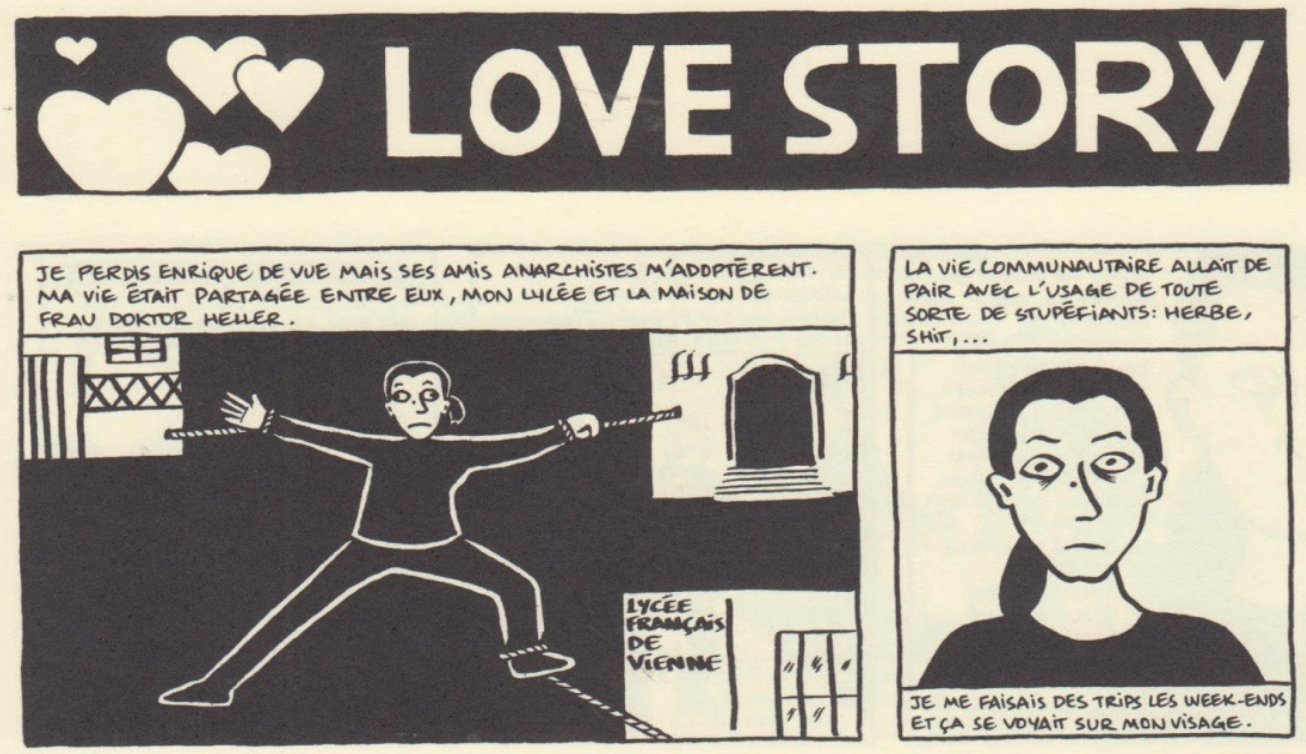

Fonte : SATRAPI, Marjani. 2011. Persepolis. França: L'Association. 

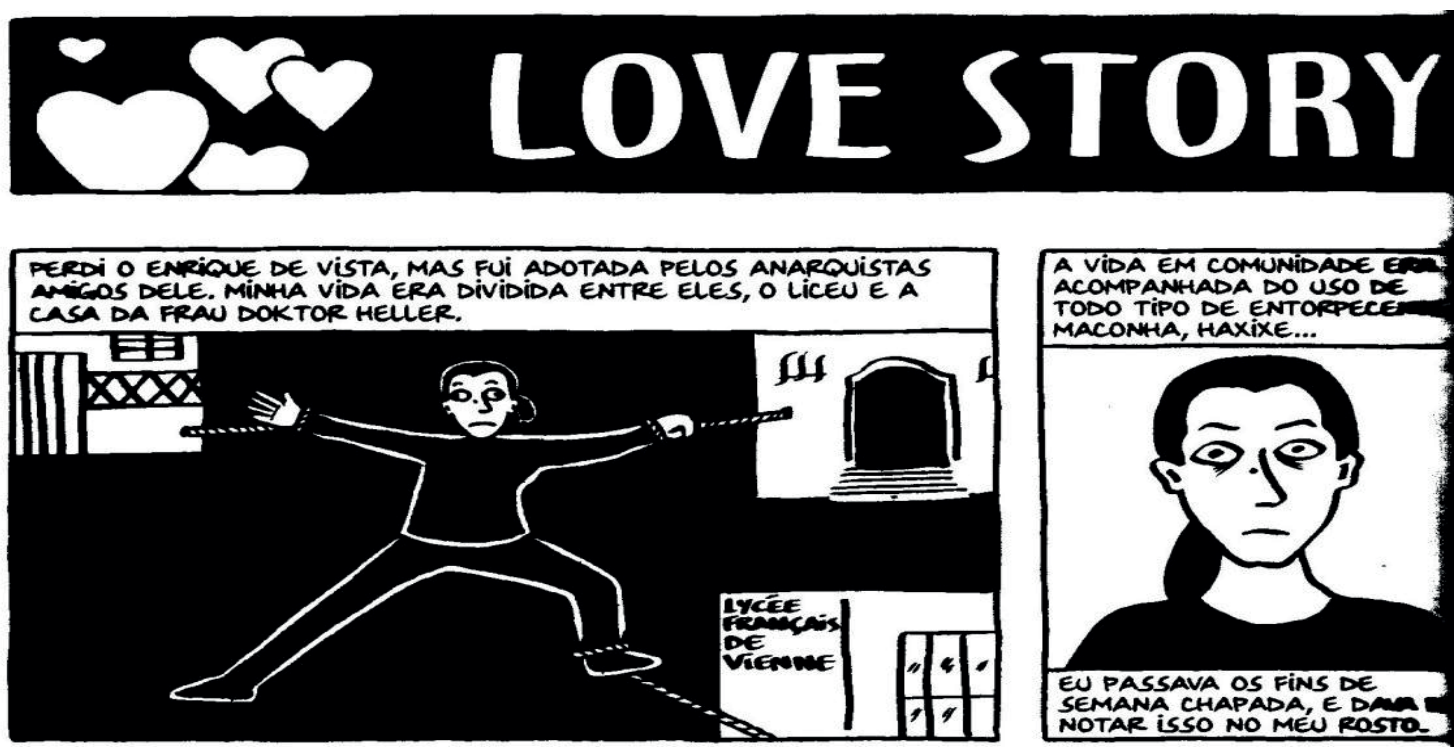

PERDi O ENREOUE DE VISTA, MAS FUI ADOTADA PELOS ANARQUISTAS CASA DA FRAU DOKTOR HELLER.

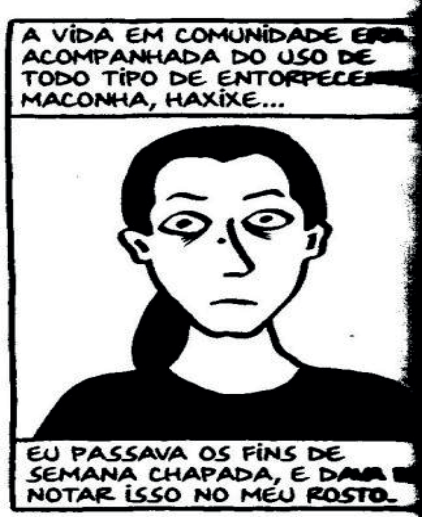

Fonte : SATRAPI, Marjani. 2007. Persépolis Completo. São Paulo: CIA das Letras.

A imagem da personagem amarrada aos locais, no requadro1, sugere a divisão de tempo de Marjani entre os amigos e outras atividades. Na sentença em francês, a autora usa a voz ativa: ses amis anarchistes $m$ 'adoptèrent que poderia ser facilmente traduzida por uma sequência direta: seus amigos anarquistas me adotaram. No entanto, pelo fato da imagem representar uma atitude pouco ativa da personagem, o tradutor, Paulo Werneck, optou pela voz passiva no português: fui adotada pelos anarquistas amigos dele. A imagem de uma ação sem a participação da personagem sugeriu uma opção verbal que também demonstrasse a passividade.

No requadro 2, em português, percebemos que o tradutor manteve o nome da escola em francês Lycée français de Vienne. Esses elementos visuais-textuais que, nos quadrinhos, não são nem cartuchos narrativos e nem fala dos personagens, são denominados inscrições. As inscrições em Persepolis aparecem tanto em farsi (principal língua do Irã) como em francês e na maioria das vezes o tradutor optou por não traduzilas. A razão dessa opção parece estar ligada ao idioma falado no momento em que essas inscrições aparecem. O tradutor precisava transmitir a ideia de que, naquele momento, a personagem conversava, lia ou ouvia o farsi ou francês.

O tradutor de quadrinhos, além de ter em mente uma definição da linguagem dos quadrinhos, precisa reconhecer nas HQ seu suporte artístico de grande importância, 
principalmente pelo seu alcance enquanto texto, literatura e produto da mídia de massas. Já em 1975, Anselmoafirmava que as HQ deveriam ser classificadas como meio de comunicação de massa (MCM) porque tinham características essenciais como:

Envolvimento com máquinas de mediação da comunicação, a impressão, por exemplo; atinge vasta audiência em breve período de tempo; as mensagens originam-se de uma ampla organização de profissionais e divisão de trabalho; reflete a educação de um povo; difundem instantânea e rapidamente mensagens; estendem a informação, a diversão e o ensino ao homem comum, combatendo privilégios no acesso à informação (ANSELMO, 1975, p. 23).

Com o desenvolvimento dos quadrinhos como um gênero textual surgiu o conceito de romance gráfico (em inglês graphic novel) que são, segundo Braga (2006), livros que contam uma história longa por meio da arte sequencial. O termo é usado para definir as distinções subjetivas entre um livro e outras histórias em quadrinhos (BRAGA, 2006, p. 67). Foi Will Eisner quem popularizou o termo romance gráfico (RG), que apareceu na capa de seu livro A contract with God (1978). No entanto, o formato de histórias em quadrinhos mais extensas e com temáticas sociais ou filosóficas tem como precursor Richard Kyle que usou o termo nos anos 1960 (BRAGA, 2006, p. 68). Atualmente, o termo se aplica a edições encadernadas publicadas para estruturar uma história longa em quadrinhos.

\section{A ORALIDADE FINGIDA E OS QUADRINHOS: DO FALADO AO ESCRI- TO REPRESENTANDO O FALADO}

Em geral, elementos da fala são transcritos para um texto escrito em passagens de diálogos com objetivos variados, dentre eles o de caracterizar as personagens, sua personalidade, sua classe social, seu grau de instrução. Brumme (2008) conceitua a oralidade fingida como as variedades de manifestações orais que se pretendem refletir no texto escrito e que são confrontadas com problemas como as diferenças culturais, a relação norma-uso, a relação oral-escrito e os recursos de uma língua para outra. A oralidade fingida também pode ser classificadacomo construída, já que há uma ilusão de que é uma representação fiel da linguagem falada na escrita.

As histórias em quadrinhos são textos que, por causa de seus recursos gráficos representados pelos requadros, balões e sarjetas, têm uma estrutura híbrida de gênero textual na qual estão presentes normas da linguagem oral e escrita e suas variações. Os 
símbolos, imagens, expressões das personagens e características da fala estruturam uma oralidade fingida (fictive orality), conceito assim definido por Sinner:

A oralidade fingida é uma variedade linguística situacional que difere da fala espontânea em vários aspectos. A fala na ficção é o produto de recriação ou evocação estilizada por parte de um autor. Embora o realismo e a autenticidade possam ser as qualidades mais celebradas, em última instância, as funções literárias e a dimensão semiótica do diálogo impõem restrições significativas sobre as decisões tomadas tanto pelos autores do texto-fonte como pelo tradutor ${ }^{1}$. (SINNER, 2009, p. 07) [tradução nossa]

Sinner (2009) chama a atenção para uma análise da oralidade fingida com o intuito de observar a representação de norma específica:

$\mathrm{Na}$ maioria dos estudos sobre oralidade fingida - realizados de uma perspectiva translatológica - se enfoca a distância da oralidade real para determinar os padrões e as convenções da representação do oral na ficção - supondo, como já assinalei, que não coincidem com a própria natureza do fictícioº (SINNER, 2009, p. 437).[tradução nossa]

$\mathrm{Na}$ narrativa feita em quadrinhos, cada personagem assume um estilo oral. Há uma espécie de marca da oralidade. Como a linguagem das HQ é composta por recursos especiais, termos especiais e ainda sofre certa oscilação dependendo das personagens, a oralidade fingida é ainda mais notável.

Segundo Guilhelm Naro (apud SINNER, 2009, p. 107), as HQ são um gênero excepcional de oralidade fingida porque constituem uma representação do oral que é aceita pelos leitores. Há marcas profundas da oralidade nas HQ e os balões são uma representação gráfica do falar. As onomatopeias, o jogo de palavras e até as interpretações

\footnotetext{
${ }^{1}$ The fictive orality, a situational linguistic variety, differing from spontaneous speech in various respects. Speech in fiction is the product of stylised recreation or evocation by an author. While realism and authenticity may be the most celebrated qualities, ultimately, the literary functions and the semiotic dimension of dialogue place significant constraints on the decisions taken both by the source text authors and the translator (SINNER, 2008, p.07).

${ }^{2}$ En el grueso de los estudios de la oralidad fingida - se han realizado muchos trabajos recientemente desde una perspectiva translatológica - se enfoca la distancia de la oralidad real, para determinar las pautas y convenciones de la representación de lo oral en la ficción suponiendo, como he señalado, que no coinciden por la propia naturaleza de lo ficticio (SINNER, 2009, p. 437).
} 
de estruturas completamente inventadas, como a fala de animais, caracterizam a linguagem das HQ e suas especificidades.

Pensando natradução e no tradutor, a predominância da representação oral na escrita das histórias em quadrinhos necessita de uma atenção especial. Uma ironia em francês pode não representar o mesmo efeito quando traduzida para o português brasileiro (daqui em diante PB). Além do mais, apesar dos balões representarem a fala dos personagens, essa representação está efetivada em um texto escrito, que limita muitos aspectos reais da oralidade.

Nos requadros a seguir, que fazem parte da prancha narrativa La fête ( $A$ festa) de Persépolis aparece um ditado infantil em francês que tem rimas: sors de ta cachette, ne sois pasmauviette! No texto traduzido para o PB, por Paulo Werneck, o ditado não foi escrito com rimas e tão pouco pareceu uma quadrinha infantil: sai do esconderijo, não seja frouxo! As escolhas do tradutor não consideraram a rima. O tradutor também não buscou expressões no PB que refletissem um ditado popular ou infantil como no texto em francês:
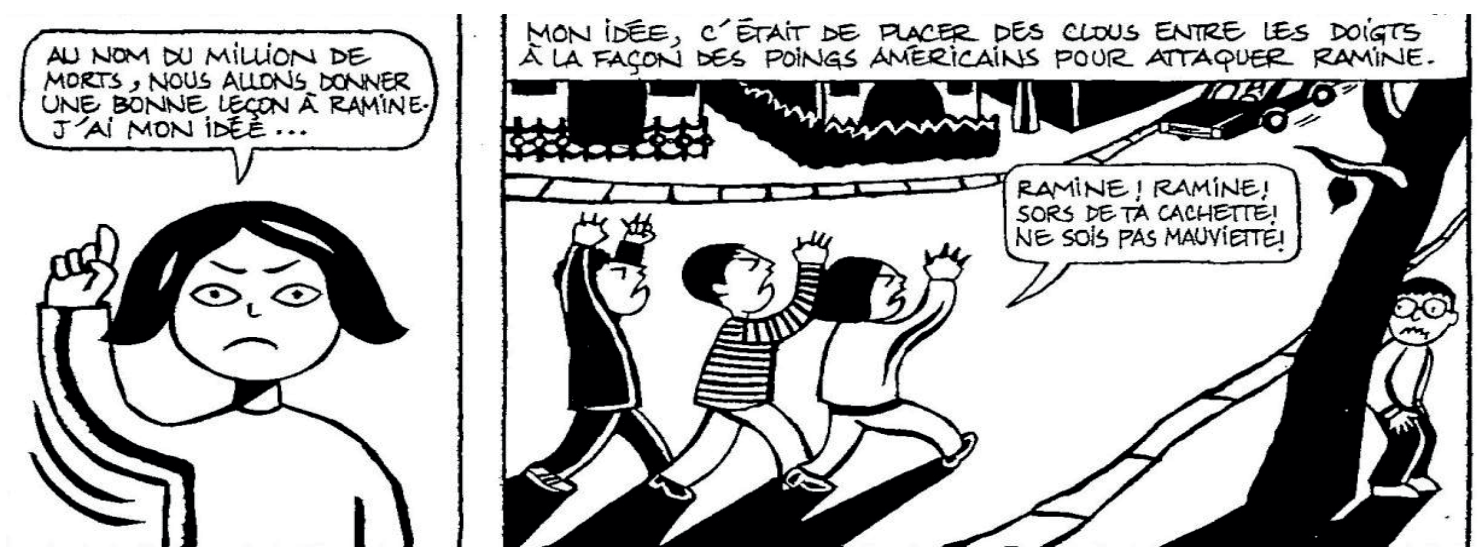

Fonte: SATRAPI, Marjani. 2011. Persepolis. França: L'Association. 

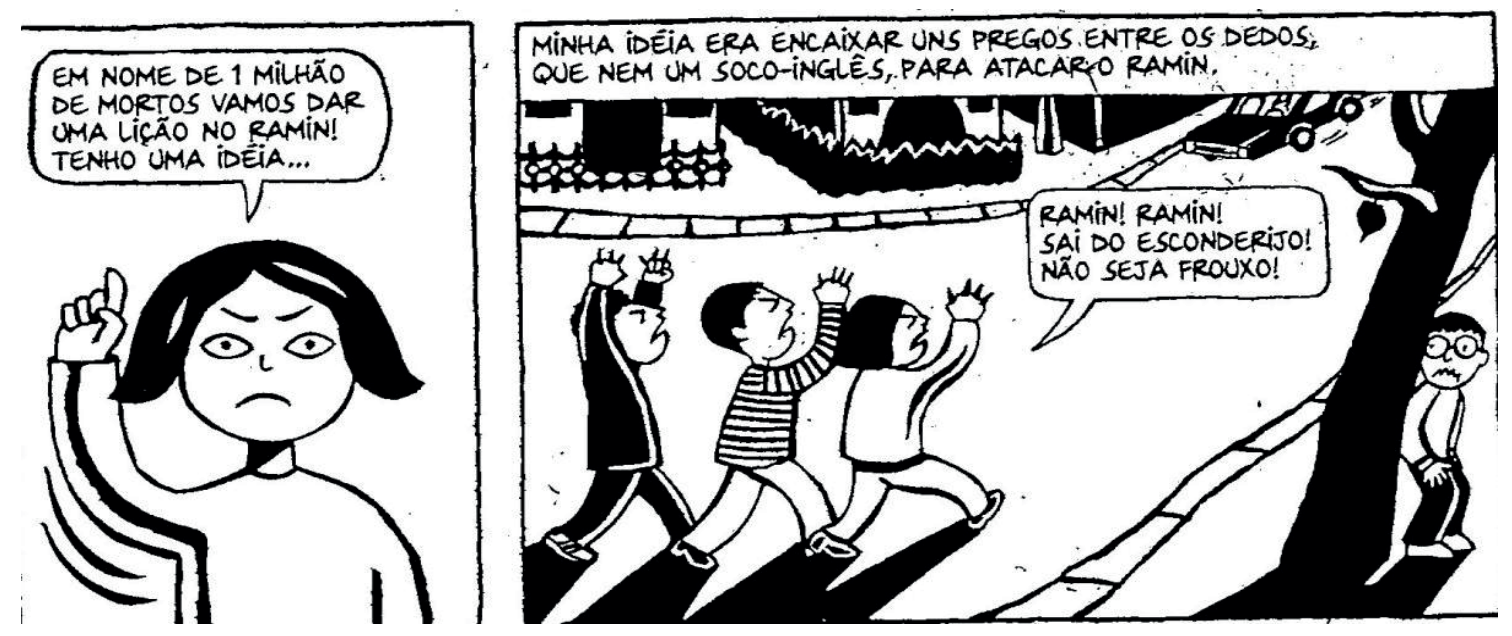

Fonte : SATRAPI, Marjani. 2007. Persépolis Completo. São Paulo: CIA das Letras.

Na tradução desses requadros, Werneck considerou a espontaneidade da fala das crianças e optou traduzir mauviette pelo adjetivo frouxo com o sentido de covarde. Outra observação diz respeito à norma do modo imperativo: conforme já é habitual no PB, há o uso simultâneo de formas atribuídas pela norma-padrão canônica ao pronome $t u$ (sai) e ao pronome você (seja). Cabe lembrar que a forma prevista por essa norma-padrão para o pronome $t u$ (sê) é totalmente desconhecida dos falantes do PB. Esse hibridismo de normas é denominado como terceiro código por Baker, que assim o explica:

O conceito de terceiro código deve ser mais explorado se quisermos explicar as peculiaridades da língua de tradução de uma forma mais matizada, como um fenômeno distinto. Por exemplo, é inegável que a copresença de códigos não é a única restrição em vigor na tradução: outras pressões podem ocorrer e contribuir para a estrutura distintiva do texto traduzido. Além disso, a própria natureza dessa copresença de códigos tem de ser esclarecida. Esta exigência surge do fato de que a mera presença de dois códigos em umúnico evento não é suficiente para distinguir a tradução de outros processos, tais como em um enunciado ou texto escrito de um aluno de uma segunda língua nos quais se reconhece igualmente que o aprendiz emprega conscientemente dois códigos $^{3}$ (BAKER, 1998, p. 3). [tradução nossa]

\footnotetext{
${ }^{3}$ La notion de troisième code doit être examinée plus à fond si nous voulons rendre compte des particularités de la langue de traduction d'une façon plus nuancée en tant que phénomène distinct. Par exemple, il est indéniable que la coprésence de codes n'est pas la seule contrainte à jouer en traduction: d'autres contraintes s'exercent et contribuent à la structuration distinctive
} 
Para Baker, o tradutor utiliza um terceiro código linguístico nas traduções. Esse código é um processo consciente ou inconsciente de representações do idioma de chegada. Variações lexicais e de normas são processadas e aparecem de forma marcante no texto traduzido.

\section{O HIBRIDISMO INEVITÁVEL DAS HQ: NORMAS E FENÔMENOS VARI- ÁVEIS QUE SE MISTURAM}

Reações contrárias a usos linguísticos costumeiros da comunidade falante se baseiam no conceito de norma-padrão. A norma padrão pode ser descrita como um modelo artificial de preceitos institucionalizados que tentam codificar os usos linguísticos de determinadas classes sociais (BAGNO, 2003, p.65).

A norma-padrão representa uma força social centrípeta que tenta conter as mudanças de uma língua em constante transformação. Por utilizar exemplos de usos descontextualizados em sua descrição, quase sempre extraídos da tradição literária, a norma-padrão, em geral, se afasta do discurso real do falante de um determinado idioma e serve muito mais como um controle de casta social do que como uma descrição científica das normas de uma língua.

A norma culta também suscita em seu histórico terminológico muitas discussões. Por trás do termo norma culta, estão dois conceitos que para Bagno (2003) são totalmente opostos: "um modelo de atividade escrita inspirado nos usos que aparecem nas grandes obras literárias criando um padrão a ser observado por qualquer falante" (p. 43) e outro conceito que "se refere à linguagem concretamente empregada pelos cidadãos que pertencem aos segmentos mais favorecidos da nossa população" (p. 51).

Em contraste com as duas normas anteriores - padrão e culta - temos a norma popular, termo que designa um conjunto de variedades que não constituem objeto de uma normatização consciente, e, por não corresponderem aos usos das classes favorecidas são consideradas como portadoras de erros e desvios. Bagno explica que a norma popular designa "as variedades linguísticas relacionadas aos falantes sem escolaridade superior completa, com pouca ou nenhuma escolarização, moradores da zona rural ou das periferias empobrecidas das grandes cidades" (p. 59).

du texte traduit. De plus, la nature même de cette coprésence de codes demande à être clarifiée. Cette exigence découle de ce que la simple présence de deux codes dans un même événement ne suffit pas à distinguer la traduction d'autres processus, tels un énoncé ou le texte écrit par un apprenant de langue seconde, où on reconnaît également que l'apprenant ou l'interlocuteur emploie consciemment deux codes (BAKER, 1998, p.3). 
Tanto norma culta como norma popular expressam conceitos com problemas de definição. Para tanto, Bagno (2003) propõe uma nova terminologia: (1) norma padrão porque exprime verdadeiramente seu sentido: um ditame, uma lei artificial e arbitrária; (2) variedades prestigiadas - termo que procura mostrar que o que está em jogo não é a língua propriamente dita, mas sim o prestígio social dos falantes (p. 65); (3) variedades estigmatizadas - caracterizam os grupos sociais desprestigiados do Brasil (p. 67).

Na Gramática pedagógica do português brasileiro (2012a), Bagno retoma o conceito de norma culta com o intuito de abranger as variedades urbanas de prestígio e adota a terminologia de português brasileirocontemporâneo, por considerar que:

É uma língua plena, perfeita para atender a todas as necessidades da interação social e da construção da identidade dos cidadãos de uma nação soberana, rica e importante. Temos que estudar e ensinar a nossa língua com base no que ela é aqui e agora, no Brasil do século XXI (BAGNO, 2012a, p. 111).

Descrever uma língua é um trabalho que parte do uso dessa língua no discurso dos falantes. Uma norma linguística nasce e se impõe na interação incessante entre discurso e gramática que para Bagno são indissociáveis.

Para a análise de normas linguísticas nesse trabalho usamos o referencial do português brasileiro contemporâneo explicitado por Bagno e a base das conclusões está ligada à ideia de que a relação norma/língua terá como ponto de partida "as formas genuinamente brasileiras de falar e escrever." (BAGNO, 2012a, p. 33).

O hibridismo é uma característica marcante no gênero quadrinhos. Na linguagem das HQ se observa o hibridismo na união entre o verbal e o não verbal. A imagem não é só um apoio gráfico da palavra, mas sim parte integrante do texto, que leva ao surgimento de um conjunto híbrido. O autor dos quadrinhos, muitas vezes, não escreve só os balões ou os cartuchos, ele também é o autor dos desenhos, seu texto é um todo configurado, hibridamente construído.

As normas linguísticas nos textos das HQ também são híbridas já que os autores procuram caracterizar personagens através das falas e também precisam submeter seu texto a uma aceitação editorial para publicação atitude que acaba por fazer incidir sobre o texto dos quadrinhos variadas representações de normas. A oralidade fingida e os agentes normatizantes influenciam nesse hibridismo de normas, tão evidente no discurso dos quadrinhos. O que chamamos aqui de agentes normatizantes são aqueles que, entre o texto entregue pelo tradutor e a obra publicada, aplicaram suas representações de uma norma 
durante o processo de produção da obra: revisores, preparadores de texto, diagramadores, editores, etc. Por isso dizemos que, no processo de tradução, ocorre um hibridismo de normas: não é o texto produzido pelo tradutor que chega intocado ao mercado, mas sim um texto resultante de diversas interferências dos agentes normatizantes.

Outra especificidade do discurso quadrinístico para o tradutor se refere à linguagem sintética das HQ. O autor das HQ é, quase sempre, quem escreve e ilustra. Todo espaço dos requadros é calculado em função dos desenhos e do espaço reservado aos cartuchos e balões. $\mathrm{O}$ tradutor não pode aumentar o tamanho do texto escrito sem modificar a distribuição do desenho no espaço. Então, é preciso que o tradutor esteja atento ao tamanho de seu texto traduzido para evitar a descaracterização do espaço dos desenhos nos requadros. Para Paulo Werneck esse foi um dos desafios na tradução de Persépolis:

k) Que diferenças há, em sua opinião, na tradução de histórias em quadrinhos e outros gêneros de texto?

Os quadrinhos são o teste fatal do diálogo e da síntese: a fala precisa caber no balão, de preferência sem perder conteúdo. Muito tradutor tarimbado tropeça justamente no diálogo (que existe também em literatura) e no poder de síntese (entrevista com Paulo Werneck, 12/09/2013 in BRAGA, Ana Cláudia Vieira, 2013, anexo I).

Em Bagno (2012b), as características de hibridismo avançam sobre o conceito de gêneros textuais e desconsideram suas diferenças como marca de especificidade. A presença de traços da fala na escrita ou vice-versa impossibilita uma rígida separação entre texto falado e texto escrito: "Nem mesmo as diferenças devidas ao gênero textual e à variação estilística podem servir hoje de argumento para qualquer tipo de distinção nítida entre fala e escrita" (BAGNO, 2012b, p. 347).

Considerando que o hibridismo está presente também nos usos das normas linguísticas do texto traduzido de Persépolis para o PB, analisamos como esse hibridismo aparece na perspectiva de representação da norma e nos traços de oralidade fingida a partir dos seguintes fatos gramaticais, também denominados fenômenos variáveis do português brasileiro: demonstrativos (formas com -ss- $e-s t$-); formas verbais no imperativo: indicativo e subjuntivo; relações pronominais você/te, você/o/a e você/lhe; uso dos verbos ter e haver e uso de nós e a gente. 


\section{METODOLOGIA DA ANÁLISE}

O Romance Gráfico (daqui para frente RG) Persépolis está dividido em quatro livros na publicação em francês, sem numeração de páginas. No texto traduzido não aparece essa divisão por livros e, para facilitar a análise dos dados, numeramos manualmente as páginas. A numeração começa na primeira página da prancha de abertura $O$ véu (p. 1) e vai até a última página da prancha $O$ fim (p. 354).

Os dados quantitativos foram tabelados por ocorrências na obra toda e fizemos um levantamento por amostragem de três pranchas das quais retiramos as transcrições para demonstrar a metodologia de análise. As três pranchas das quais retiramos as ocorrências para uma análise mais detalhada foram Moscou, A sopa e Love story.

Apresentaremos as normas das ocorrências linguísticas do PB analisadas tendo como referencial o português brasileiro contemporâneo a partir de uma relação norma/ língua que descreve "as formas genuinamente brasileiras de falar e escrever" (BAGNO, 2012b, p. 33).

\section{Exemplo da análise}

Na impossibilidade de apresentamos, em sua totalidade, a análise desenvolvida em todas as pranchas, já que isso acarretaria um texto muito extenso para um artigo, apresentaremos a seguir as tabelas completas com os dados das ocorrências presentes nas três pranchas analisadas e o exemplo da análise de uma das pranchas, Moscou, com o fim de esclarecer como foi feito o levantamento dos dados coletados na análise das normas das ocorrências e variações linguísticas do PB.

\section{Pronomes demonstrativos - formas -ss- e -st-}

O pronomes demonstrativos aparecem em Persépolis nas duas formas -ss- (isso, essa e flexões) e -st- (isto, esta e flexões). A tabela abaixo apresenta o levantamento quantitativo das ocorrências no texto de Persépolis em PB, essas ocorrências foram consideradas tanto nos balões como nos cartuchos: 
Tabela 1: total de ocorrências

\begin{tabular}{|c|c|c|}
\hline FORMAS & $\mathrm{N}^{\mathrm{o}}$ & $\%$ \\
\hline -ss- & 196 & 84 \\
\hline -st- & 37 & 16 \\
\hline TOTAL & 233 & 100 \\
\hline
\end{tabular}

Fonte: Os autores.

A preferência pelas formas -ss- é evidente ao considerarmos o número de ocorrências. Em algumas situações aparecem as duas formas em uma mesma prancha e até mesmo em uma mesma situação de distância do objeto em relação ao falante.

Com facilidade encontramos pranchas completas sem nenhuma ocorrência da forma -st- e em outras, quando o interlocutor aponta o objeto a ser demonstrado, não tem distinção de norma no uso das formas -ss- e -st-.

Tabela 2: levantamento de dados da prancha Moscou

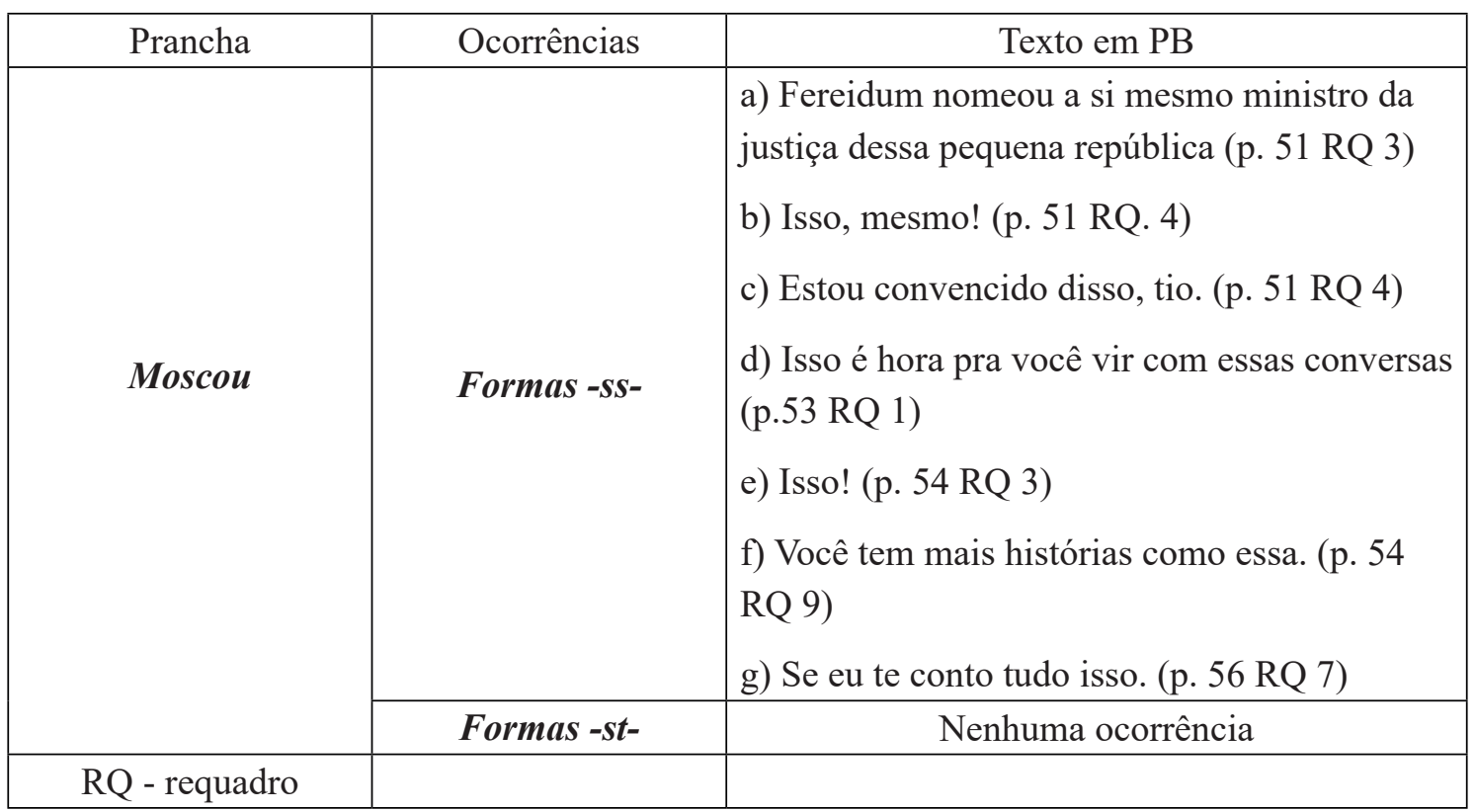

Fonte: Os autores. 
Para ilustrar, apresentamos a prancha da p. 51 (SATRAPI, 2011) na qual o emprego da forma dessa no requadro 3, isso no requadro 4 e disso no requadro 5 evidenciam a preferência pelas formas $-S S$-.

No primeiro requadro as falas: vê se não chateia e tá bom, pode ir são traços de oralidade fingida, pois são expressões que fazem parte da fala espontânea. No segundo requadro a interjeição $u a u$ ! expressa a admiração de Marjane e também é um traço de oralidade fingida.

No requadro 4, a linguagem icônica aparece em um balão no formato de explosão e evidencia a irritação e o grito do personagem.
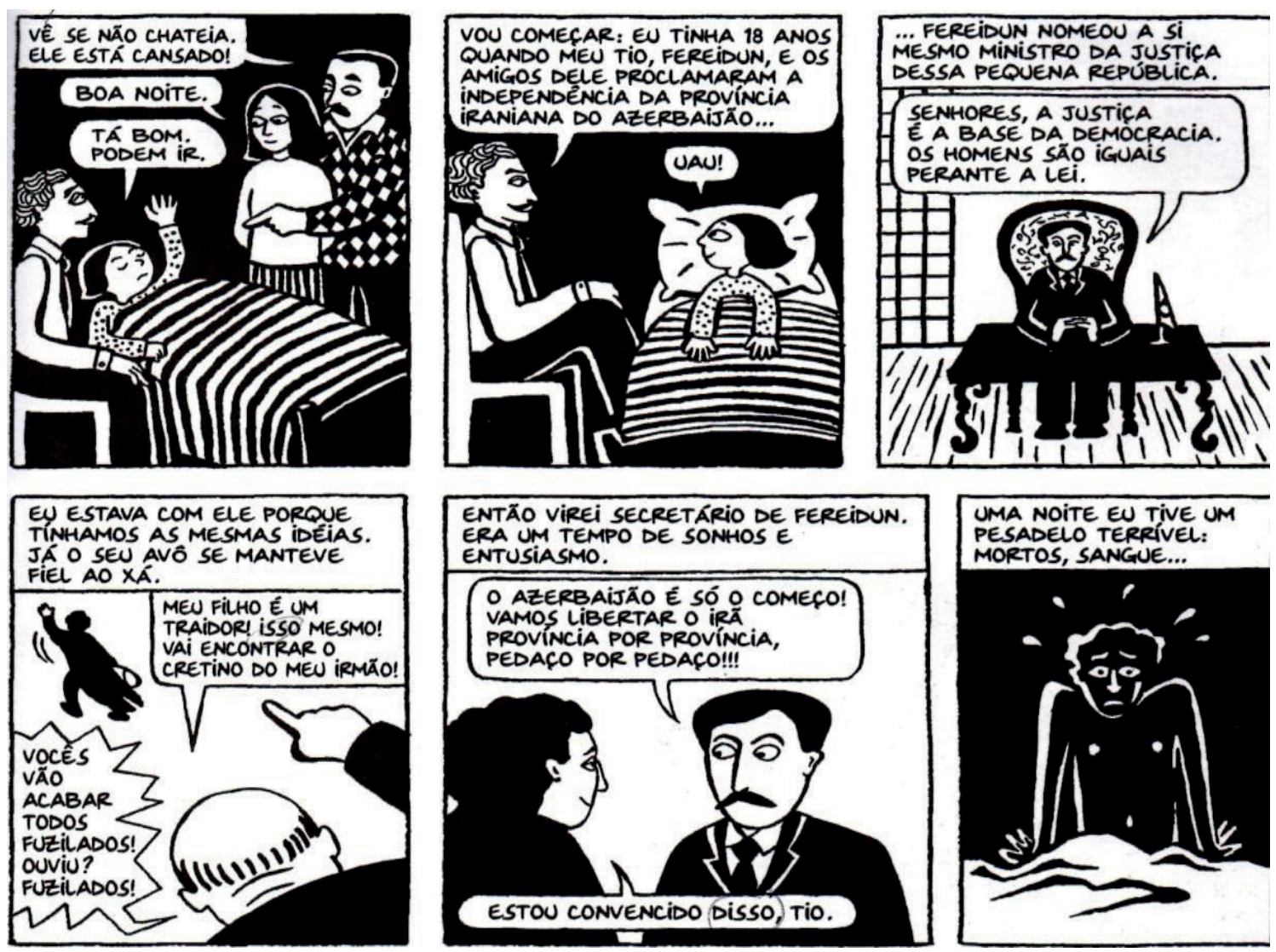

Na próxima tira, da p. 53, (SATRAPI, 2011), no requadro 1 aparecem dois usos das formas -sS-. No requadro 2, as reticências evidenciam a linguagem icônica e a oralidade fingida. Para esse contexto a ideia de suspensão demonstra a apreensão do pai com a doença do filho. 


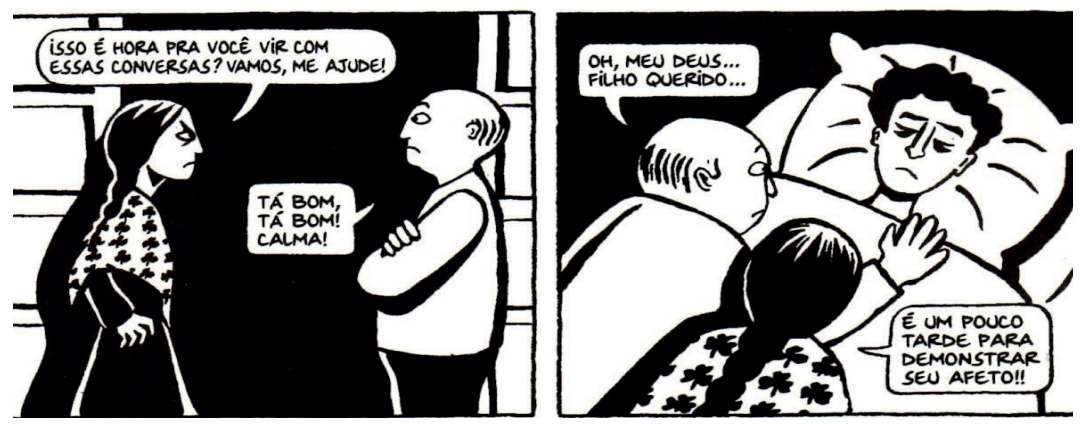

A língua oral tem muitos espaços para renovação e reestruturação das frases. É possível imaginar um diálogo no qual alguém repete palavras e não completa suas sentenças. Por isso, para representar a língua oral com a língua escrita, as reticências são muito usadas como marca de oralidade fingida. Na próxima prancha da p. 54 aparecem três empregos que expressam sentimentos diferentes, no requadro 6, a tristeza; no requadro 8 , a ideia de continuidade; no requadro 9 , a distração e suspensão de pensamento.
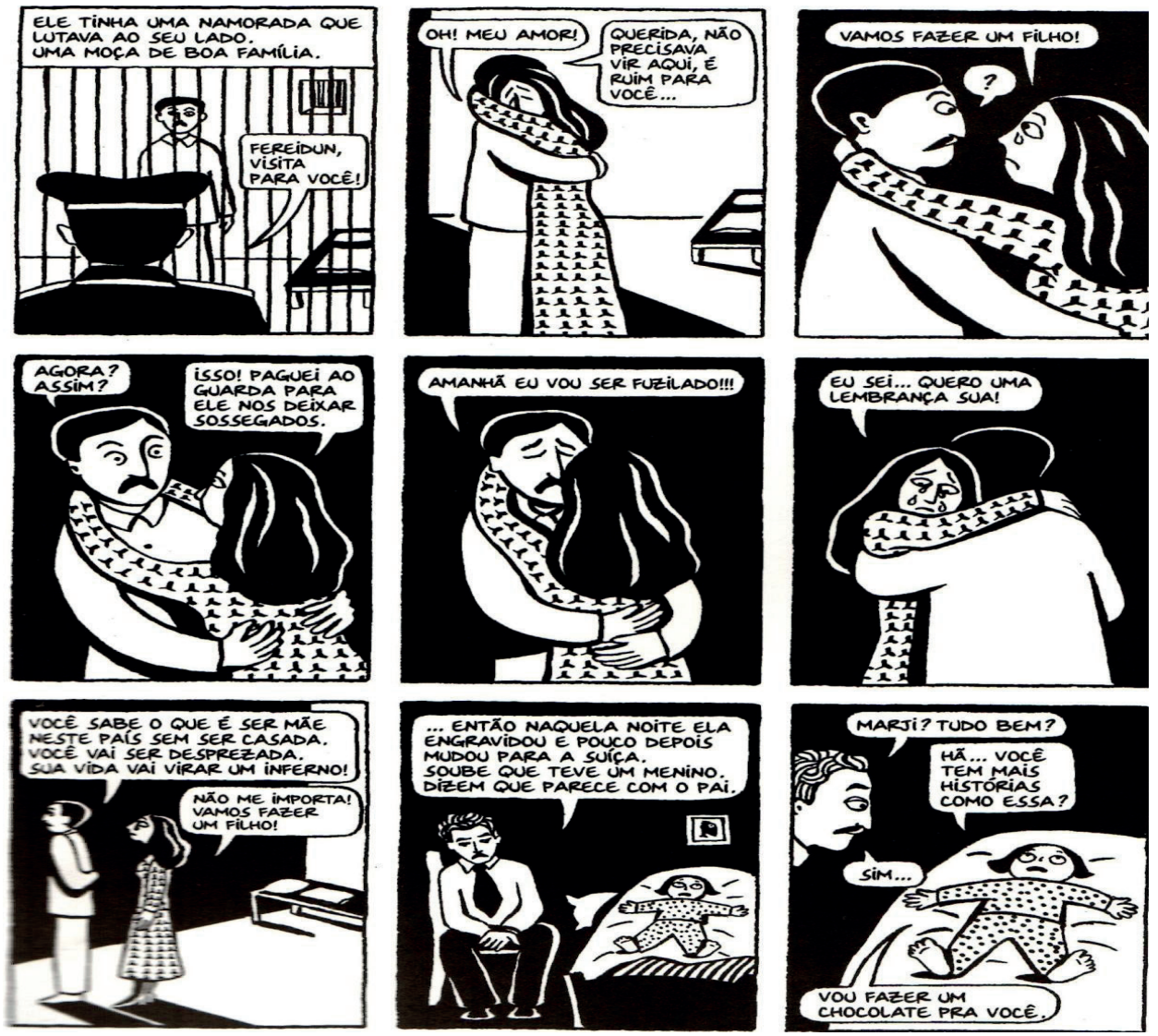
Na próxima tira, da p.56, há mais uma ocorrência da forma-ss- no requadro 3. As exclamações repetidas, também no requadro 3, são marca de linguagem icônica e oralidade fingida e expressam a necessária ênfase aos sentimentos de revolta da personagem.
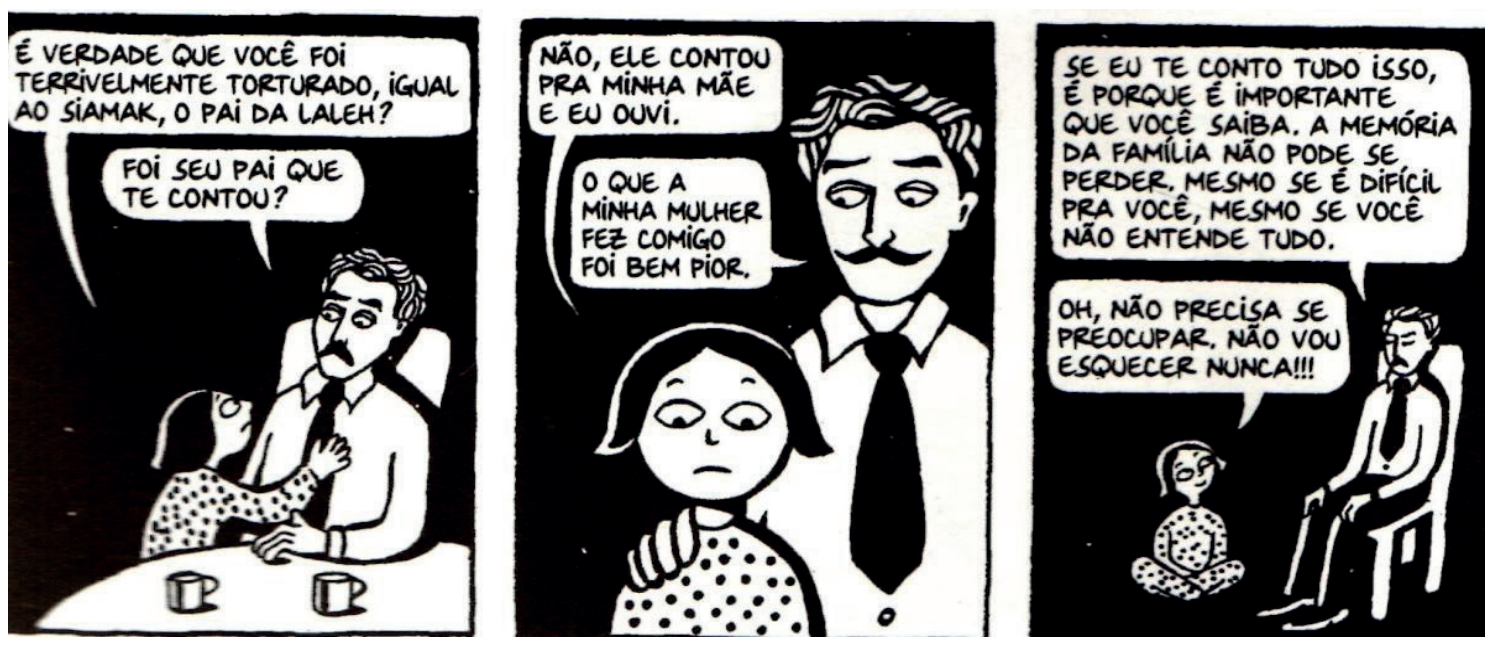

Imperativo - indicativo/ subjuntivo

O uso do imperativo no PB se relaciona com o emprego dos modos subjuntivo ou indicativo. Em Persépolis não aparece nenhuma forma $t u$ como pronome de tratamento ou pessoal, por isso analisamos as ocorrências de você com subjuntivo e você com indicativo, como nos exemplos faça (você) / faz (você).

Ao considerarmos as normas do PB para o imperativo foi possível verificar que o fenômeno da inversão de formas oriundas do indicativo e subjuntivo é comprovado no texto traduzido de Persépolis. Na gramática tradicional do português o imperativo afirmativo na $2^{\text {a }}$ pessoa do singular é formado pela retirada do $-s$ final da conjugação do presente do indicativo: tu estudas, no presente, se conjuga no imperativo estuda [tu]. Com o pronome você, o imperativo virá da terceira pessoa do singular (ele) do subjuntivo presente: [que] ele fale no presente do subjuntivo, se conjuga fale você no imperativo.

Visto que em Persépolis não se usa $t u$, todas as formas de imperativo deveriam, pelas regras gramaticais, apresentarem as formas oriundas do subjuntivo, mas pela análise quantitativa, isso não se comprova. O que temos é uma maioria de formas oriundas do indicativo. 
Outra observação importante diz respeito à primeira pessoa do plural. O imperativo de nós aparece na formação ir seguido de infinitivo. A tabela a seguir indica o número de ocorrências:

Tabela 3: total de ocorrências

\begin{tabular}{|c|c|c|}
\hline FORMAS & $\mathrm{N}^{\mathbf{0}}$ & $\%$ \\
\hline INDICATIVO & 105 & 78 \\
\hline SUBJUNTIVO & 29 & 22 \\
\hline TOTAL & 134 & 100 \\
\hline
\end{tabular}

Fonte: Os autores.

Pela ótica da gramática normativa, só seria possível usar as formas no subjuntivo, mas o tradutor preferiu seguir os usos normais brasileiros. Vejamos o exemplo de análise na prancha Moscou:

Tabela 4: levantamento de dados da prancha Moscou

\begin{tabular}{|c|c|l|}
\hline Prancha & \multicolumn{1}{|c|}{ Ocorrências } & \multicolumn{1}{|c|}{ Texto em PB } \\
\hline \multirow{4}{*}{ Moscou } & a) Dá um tempo, Marji (p. 50 RQ 7) \\
& b) Vê se não chateia. (p. 51 RQ 1) \\
& Inperativo & c) Vai encontrar o cretino do seu irmão. (p. \\
& & 51 RQ 4) \\
& Imperativo & d) Olha só. (p. 55 RQ 4) \\
& e) Toma um presente. (p. 57 RQ 3) \\
\cline { 2 - 4 } & Subjuntivo/você & g) Tenha bons sonhos. (p. 57 RQ 3) \\
\hline RQ requadro & & \\
\hline
\end{tabular}

Fonte: Os autores.

Na próxima tira, da p. 50, (SATRAPI, 2011) da história Moscou, o contexto é bem informal. O pai de Marjane chama a atenção da filha e utiliza o imperativo oriundo do presente do indicativo dá (você) no requadro 3. Ele usa uma expressão fixa "dá um tempo", extremamente informal e que só se usa com verbo no indicativo. 

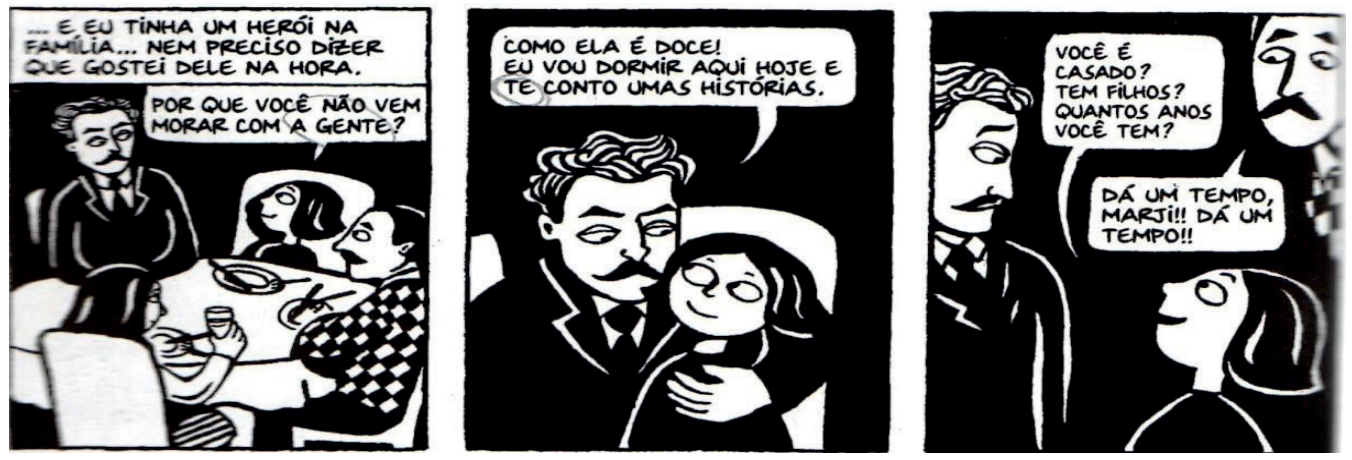

Novamente em um contexto informal, no requadro 1, o pai de Marjane fala com a filha e usa a forma $v \hat{e}$ (você). No requadro 4, o avô de Marjane fala com o filho e também aparece o fenômeno da inversão de formas do imperativo. Os traços de oralidade fingida reforçam o contexto informal. Marjane usa a intejeição uau!, no requadro 2, que tem no texto um papel icônico, e as reticências do requadro 3 indicam a continuidade da história. No requadro 4 o balão explosão revela um sentimento de raiva do avô de Marjane.
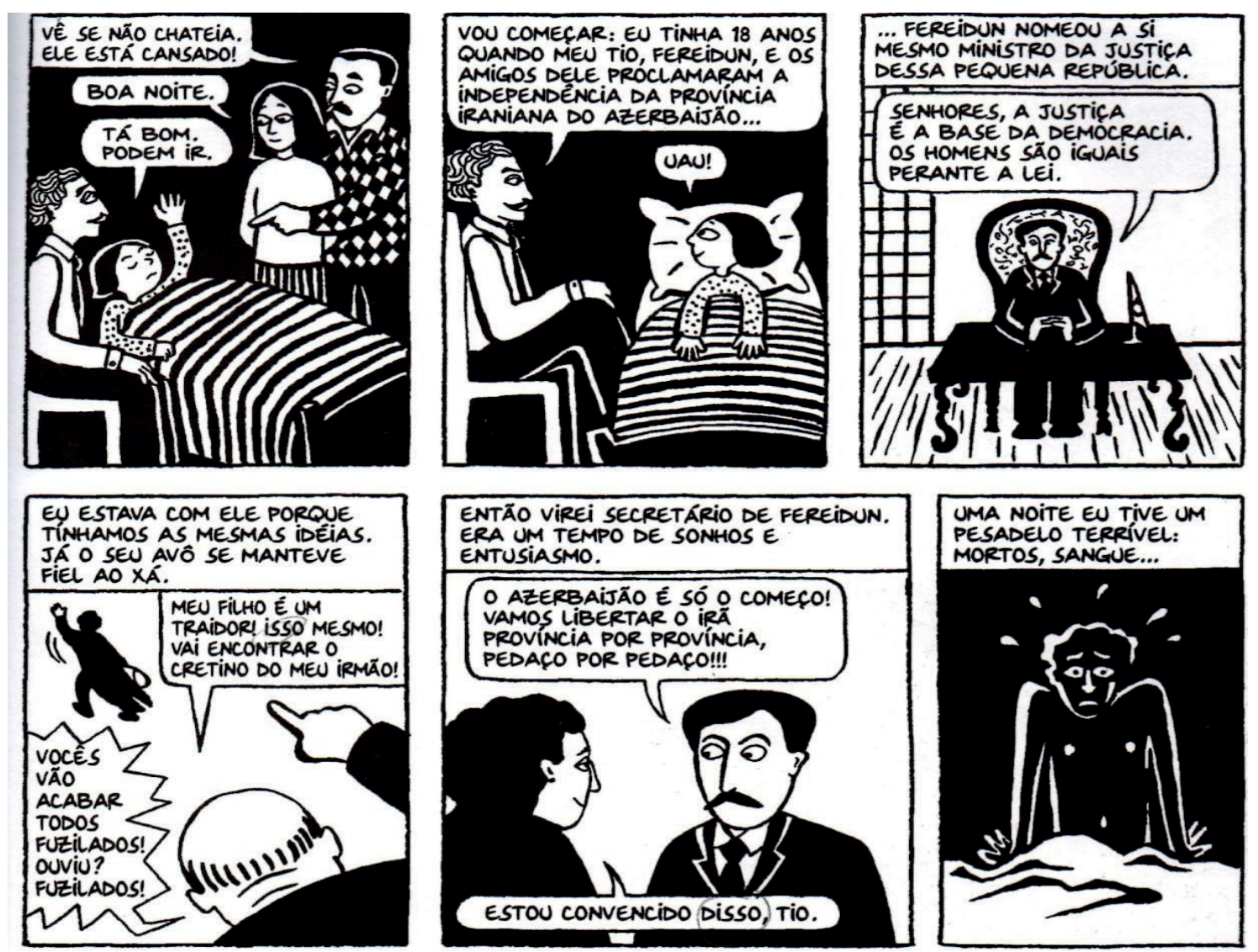

Revista X, v. 15, n. 2, p. 64-95, 2020. 
Na tira a seguir, requadro 1, o imperativo aparece na forma me ajude oriunda do subjuntivo, mas não podemos dizer que é um contexto formal e nem uma construção coerente com as regras postuladas pela gramática tradicional já que a frase começa com um pronome oblíquo fato que é considerado inadequado nas descrições tradicionais das normas de língua portuguesa. A forma vamos reforça a função conativa da frase. Um traço de oralidade fingida é a repetição de palavras ou frases, no requadro 1, Tá bom, tá bom!
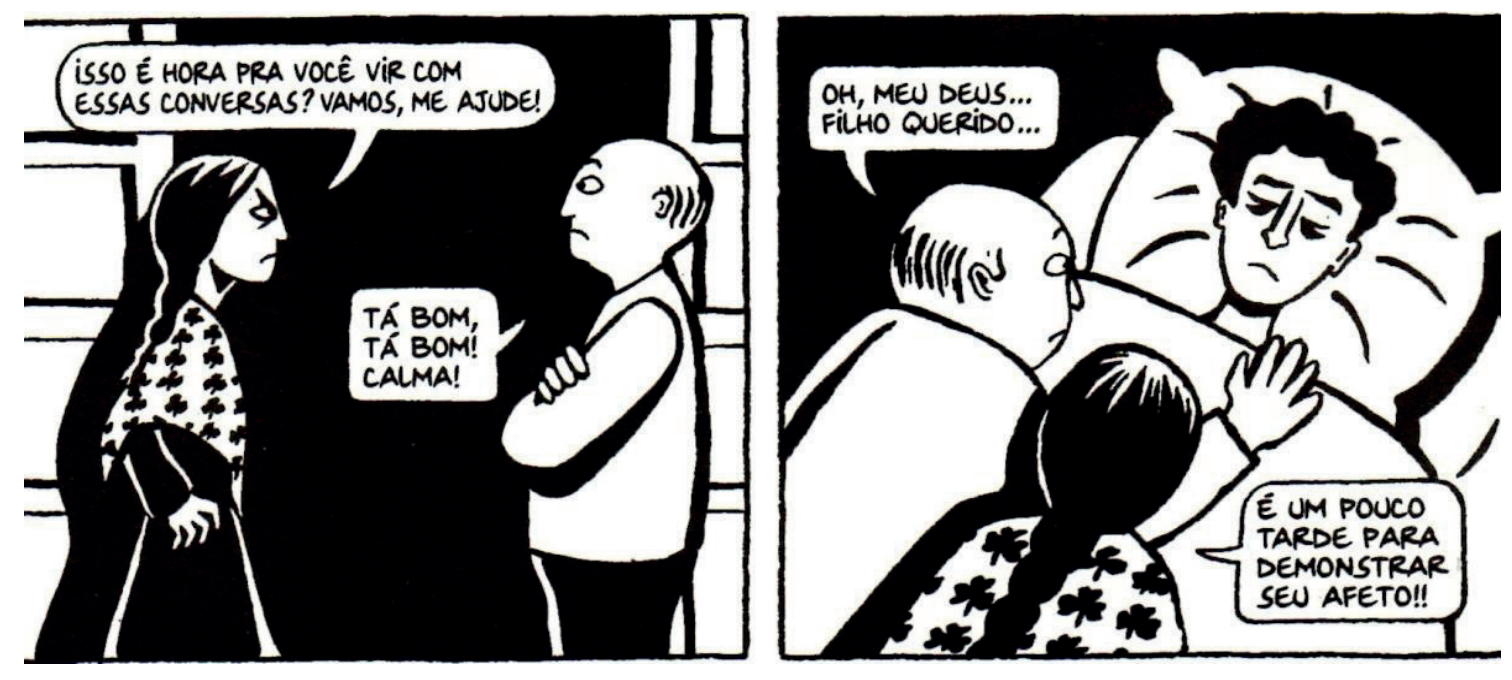

Um exemplo de imperativo na primeira pessoa do plural: vamos fazer usado em sua forma ir + infinitivo aparece no requadro 3 da próxima tira. A interrogação sozinha, requadro 3, aparece nos balões e é um traço de linguagem icônica. É possível entender que o personagem ficou em dúvida ou mesmo não compreendeu o que foi dito. Apenas um sinal de pontuação representa muitas palavras, demonstrando os recursos possíveis que são usados na linguagem sintética nas HQ. 

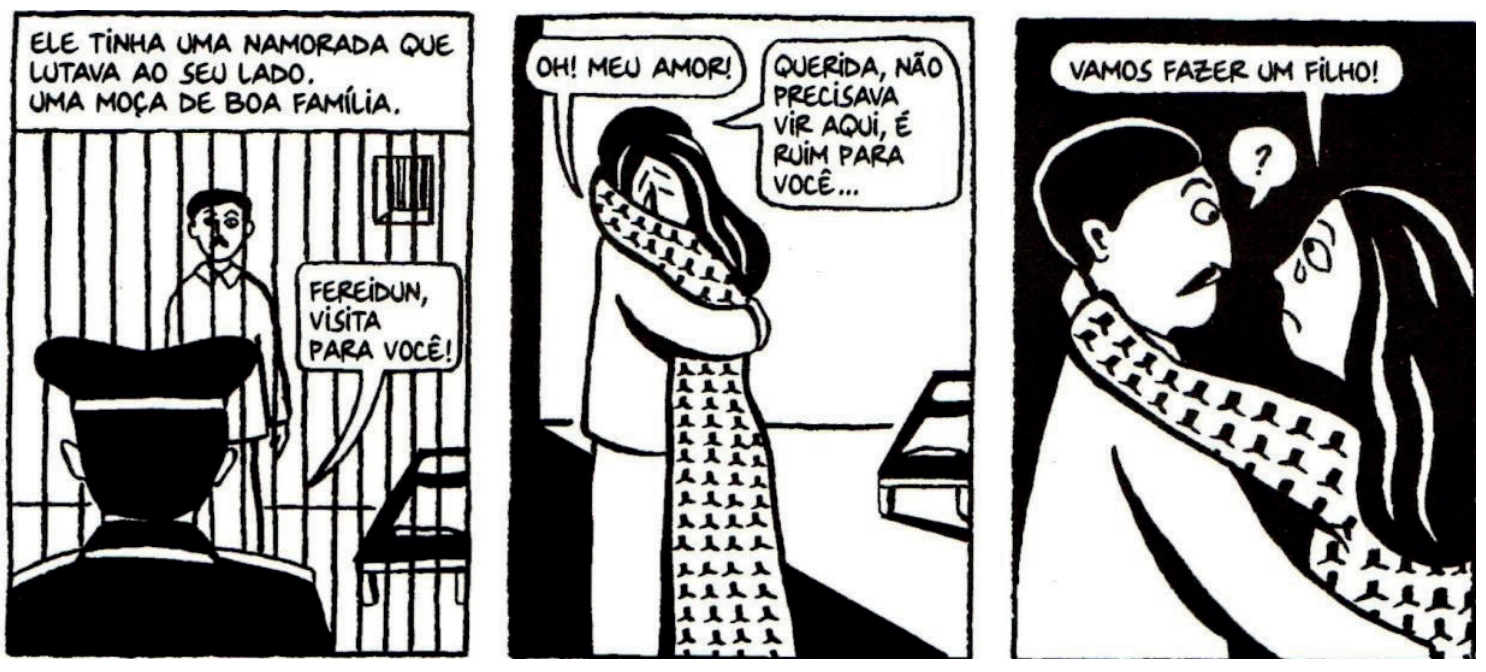

Na próxima tira um exemplo de hibridismo de normas. Em um mesmo contexto o personagem usa as formas do imperativo oriundas do indicativo e do subjuntivo: toma requadro 2 e tenha requadro 3. Nós brasileiros nunca usamos "tem" no imperativo, por isso soaria estranho "tem bons sonhos"; daí o uso que o tradutor fez de "tenha".
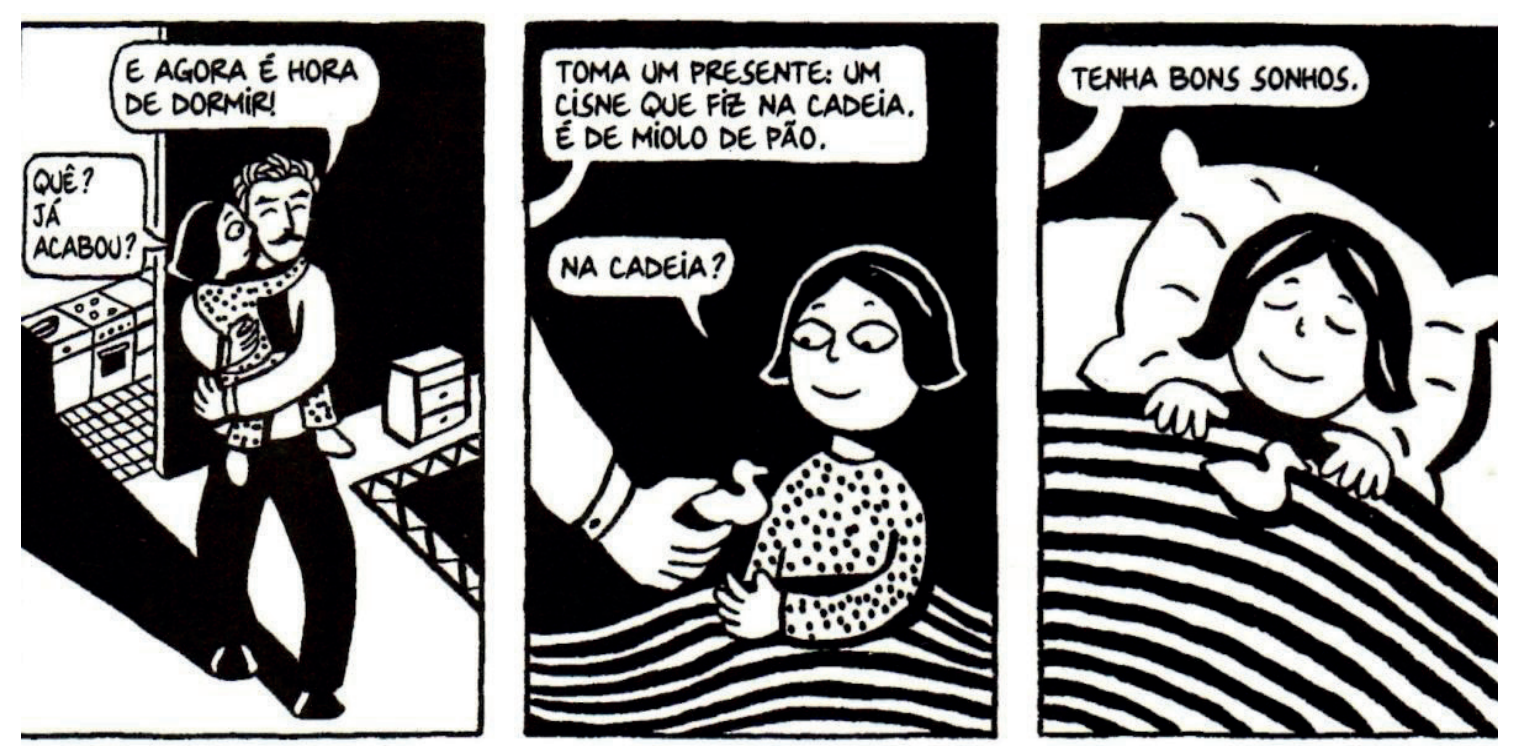


\section{Relações pronominais}

No RG Persépolis não aparece nenhuma ocorrência de lhe como objeto direto em relação a você. Nunca é usada a forma tu e a predominância da correlação vocÊ $\rightarrow$ TE é de $90 \%$ nas ocorrências.

Tabela 5: total de ocorrências

\begin{tabular}{|c|c|c|}
\hline CORRELAÇÃO & $\mathrm{n}^{\mathrm{o}}$ & $\%$ \\
\hline VOCÊ $\rightarrow$ TE & 85 & 90 \\
\hline VOCÊ $\rightarrow$ O/A & 9 & 10 \\
\hline VOCÊ $\rightarrow$ LHE (OBJ. DIRETO) & 0 & 0 \\
\hline TOTAL & 94 & 100 \\
\hline
\end{tabular}

Fonte: Os autores.

$\mathrm{Na}$ análise da prancha Moscou, os resultados foram confirmados:

Tabela 6: ocorrências na prancha Moscou

\begin{tabular}{|c|c|c|}
\hline Prancha & Ocorrências & Texto em PB \\
\hline \multirow[t]{3}{*}{ Moscou } & $\begin{array}{c}\text { Correlação } \\
\text { Você } \rightarrow \text { te }\end{array}$ & $\begin{array}{l}\text { a) Eu vou dormir aqui hoje e te conto umas } \\
\text { histórias. (p.50 RQ 6) } \\
\text { b) Foi o seu pai que te contou. (p. } 56 \text { RQ 7) } \\
\text { c) Se eu te conto tudo isso, é porque é } \\
\text { importante que você saiba. (p.56 RQ 7) }\end{array}$ \\
\hline & $\begin{array}{l}\text { Correlação } \\
\text { Você } \rightarrow o / a\end{array}$ & Nenhuma ocorrência \\
\hline & $\begin{array}{l}\text { Correlação } \\
\text { Você } \rightarrow \text { lhe }\end{array}$ & Nenhuma ocorrência \\
\hline RQ- requadro & & \\
\hline
\end{tabular}

Fonte: Os autores.

$\mathrm{Na}$ tira a seguir, da página 50, o tio conversa com Marjane. No requadro $1 \mathrm{a}$ sobrinha usa você para falar com o tio e logo depois, no requadro 2 , o adulto usa te. 

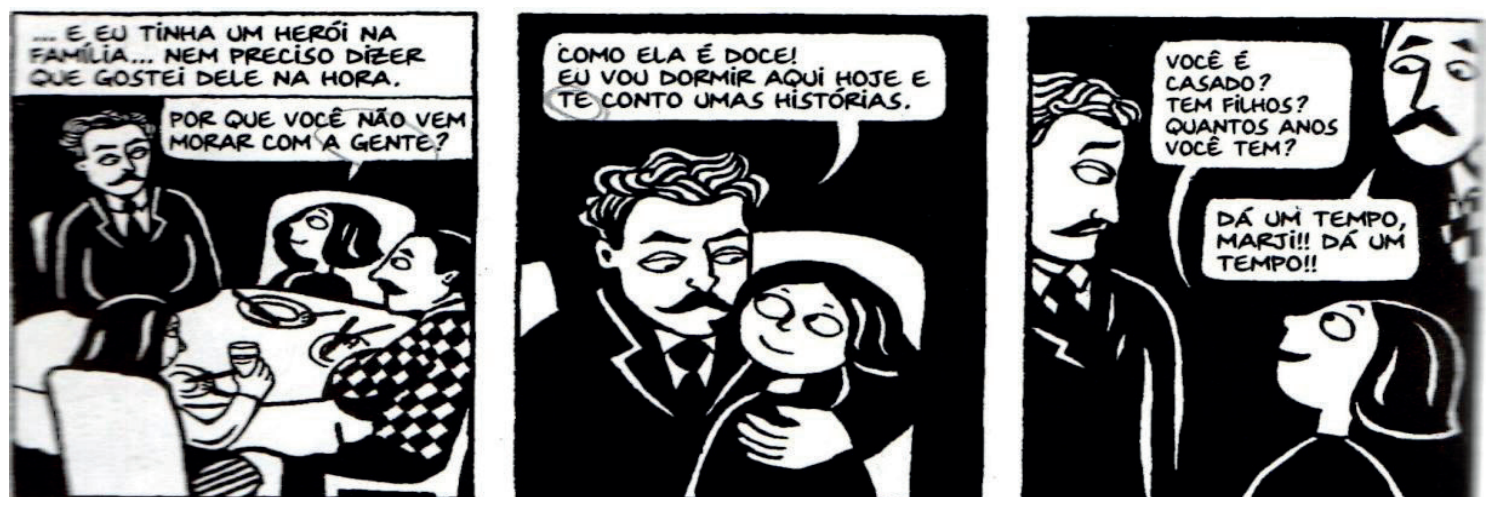

Em seguida, no requadro 3 da próxima tira, um exemplo no qual você e te aparecem em um mesmo balão:
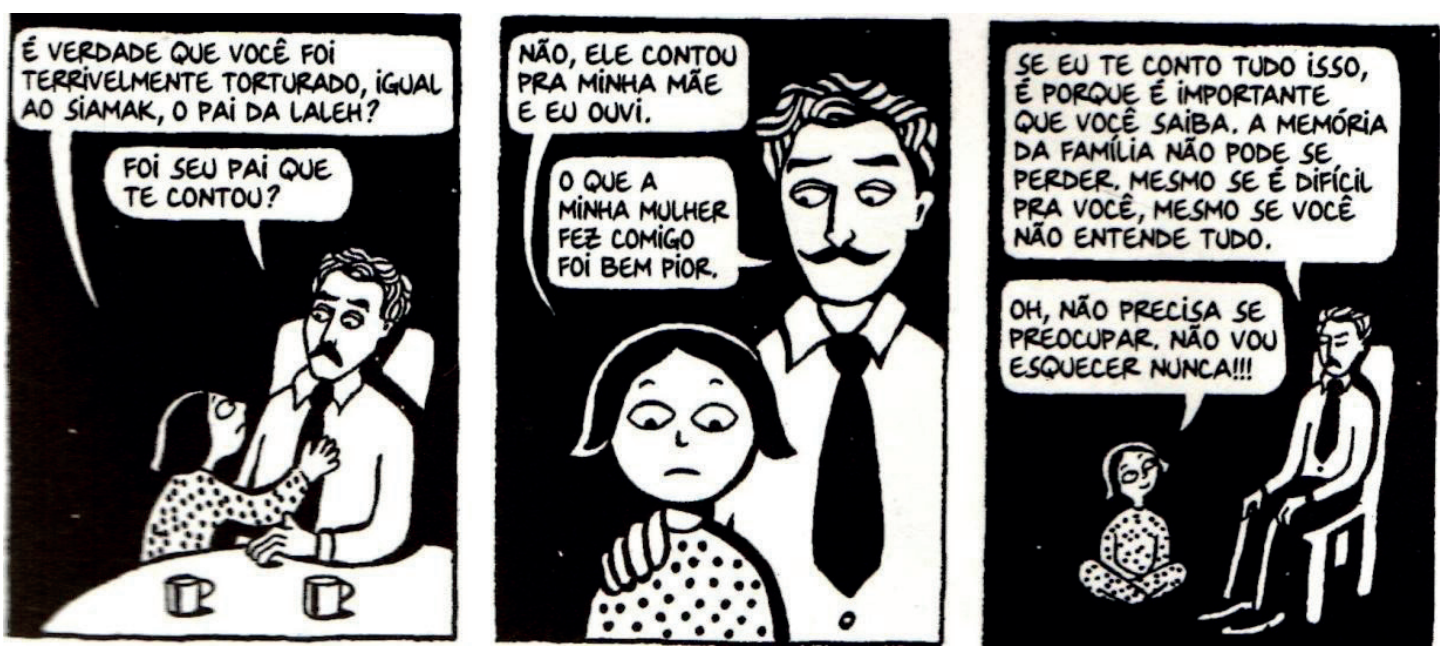

Verbos ter e haver

O verbo ter no sentido de "existir" já se encontra consagrado pelo uso na fala de muitos brasileiros, até mesmo na fala de brasileiros escolarizados. Em Persépolis o verbo ter com sentido existencial e também na formação de tempos compostos é empregado em $62 \%$ das ocorrências: 
Tabela 7: total de ocorrências

\begin{tabular}{|c|c|c|}
\hline FORMAS & $\mathrm{N}^{\mathbf{0}}$ & $\%$ \\
\hline TER & 49 & 62 \\
\hline HAVER & 29 & 38 \\
\hline TOTAL & 78 & 100 \\
\hline
\end{tabular}

Fonte: Os autores.

Nas pranchas analisadas detalhadamente não apareceu nenhuma ocorrência do verbo haver. Como nas HQ a presença da oralidade fingida influencia no discurso, o verbo ter com função existencial aparece em maior número, confirmando o hibridismo das normas e também da oralidade fingida.

Tabela 8: total de ocorrências na prancha Moscou

\begin{tabular}{|c|l|l|}
\hline Prancha & Ocorrências & \multicolumn{1}{|c|}{ Texto em PB } \\
\hline \multirow{4}{*}{ Moscou } & Verbo ter & $\begin{array}{l}\text { a) Se pelo menos tivesse sido preso. } \\
\text { (p.50 RQ 2) } \\
\text { b) Na minha família tem muitos heróis } \\
\text { (p.57RQ4) }\end{array}$ \\
\hline RQ - requadro & Verbo haver & \multicolumn{1}{|c|}{ Nenhuma ocorrência } \\
\hline & & \multicolumn{1}{|c|}{} \\
\hline
\end{tabular}

Fonte: Os autores.

O verbo ter aparece em maior número na formação de tempos compostos em Persépolis como mostra o exemplo da próxima tira da p. 50 requadro 2 : 

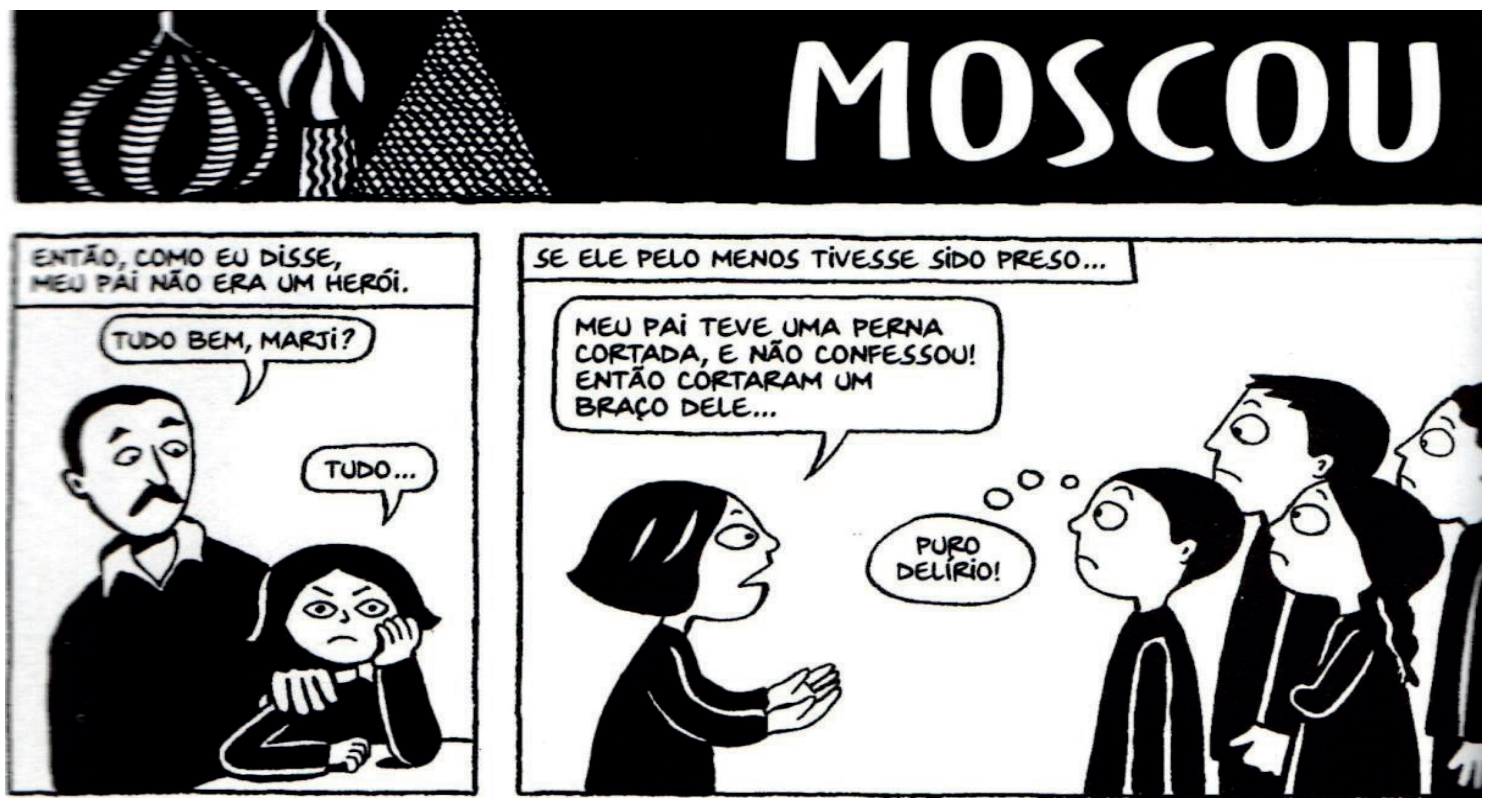

A seguir, na p. 57, um uso de ter no sentido de "existir":

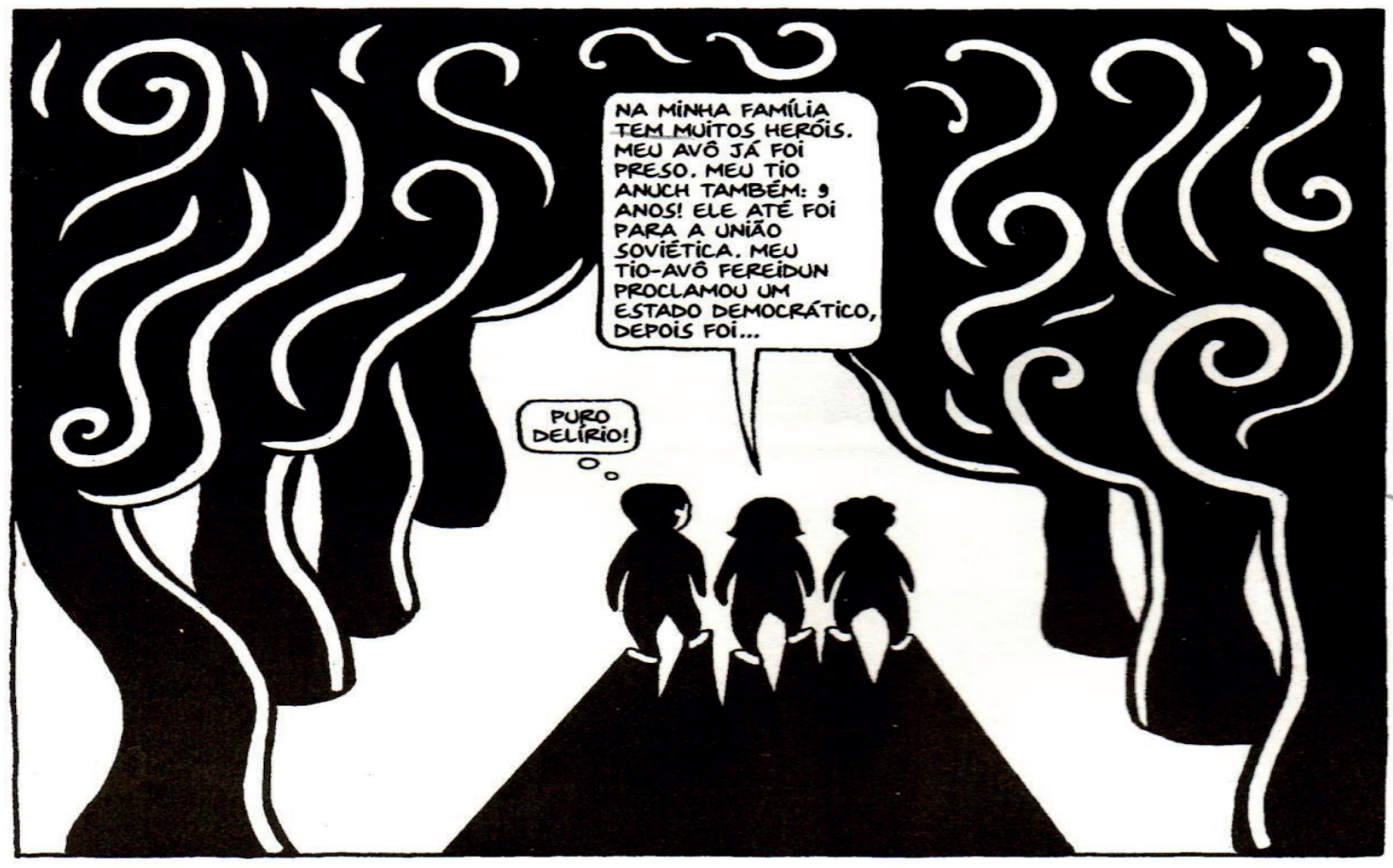




\section{A gente e nós}

$\mathrm{O}$ uso de a gente vem ganhando espaço no PB. Em Persépolis aparece um equilíbrio entre o uso de nós e a gente:

Tabela 9: total de ocorrências

\begin{tabular}{|c|c|c|}
\hline PRONOMES & $\mathrm{N}^{\mathrm{o}}$ & $\%$ \\
\hline NÓS & 115 & 51 \\
\hline A GENTE & 110 & 49 \\
\hline TOTAL & 225 & 100 \\
\hline
\end{tabular}

Fonte: Os autores.

Na prancha Moscou as ocorrências encontradas foram:

Tabela 10: ocorrências na prancha Moscou

\begin{tabular}{|c|c|l|}
\hline Prancha & Ocorrências & \multicolumn{1}{c|}{ Texto em PB } \\
\hline \multirow{2}{*}{ Moscou } & Nós & $\begin{array}{l}\text { a) Nós nos divorciamos. (p.55 RQ 6) } \\
\text { b) Os russos não são como nós. (p.55 RQ 8) }\end{array}$ \\
\cline { 2 - 3 } & A gente & $\begin{array}{l}\text { c) Por que você não vem morar com a gente. } \\
\text { (p. 50 RQ 5) }\end{array}$ \\
\hline RQ - requadro & \multicolumn{2}{|l}{} \\
\hline
\end{tabular}

Fonte: Os autores.

Para análise, vamos considerar se o contexto é formal ou informal. As marcas de oralidade fingida relacionadas às ocorrências de normas se mostram bem explicitadas nos usos de nós e a gente no PB. Em contexto de fala espontânea mais monitorada aparece mais a forma nós. Mas, como já dissemos, o hibridismo de normas é também fator determinante na análise do RG Persépolis.

$\mathrm{Na}$ tira a seguir, Marjane é uma criança e usa em um contexto informal a gente: 

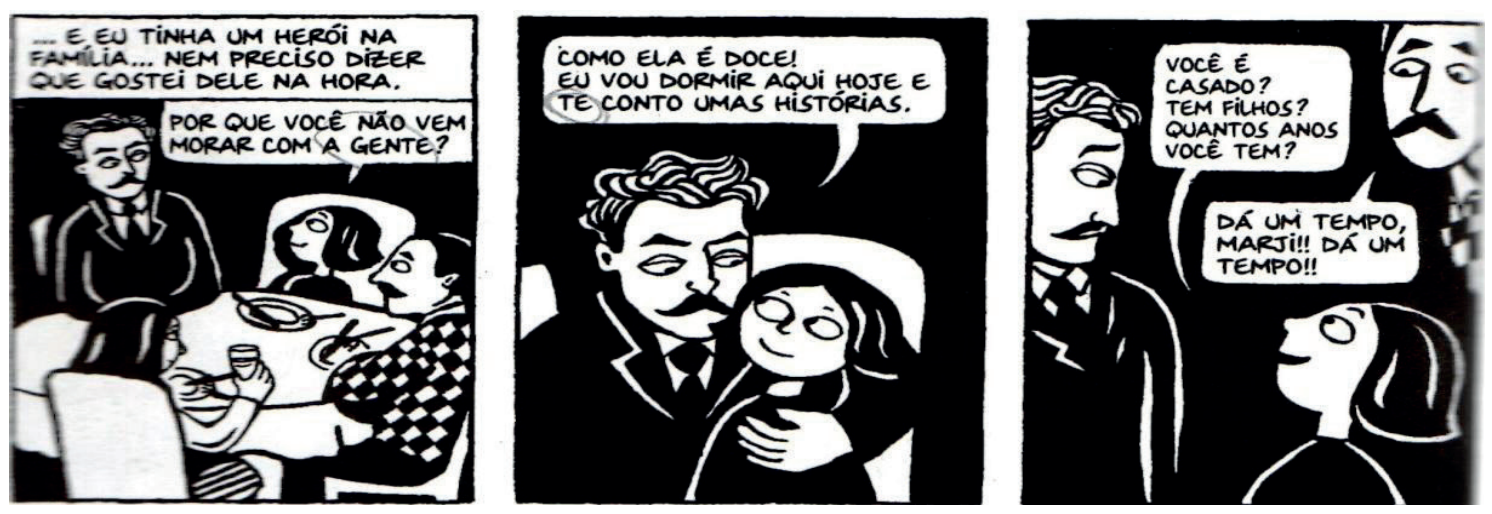

Na próxima tira no requadro, quando o tio de Marjane conta sobre sua experiência familiar, ele emprega nós em sua fala. Apesar de estar conversando com a sobrinha pequena, o tio usa uma linguagem mais formal:
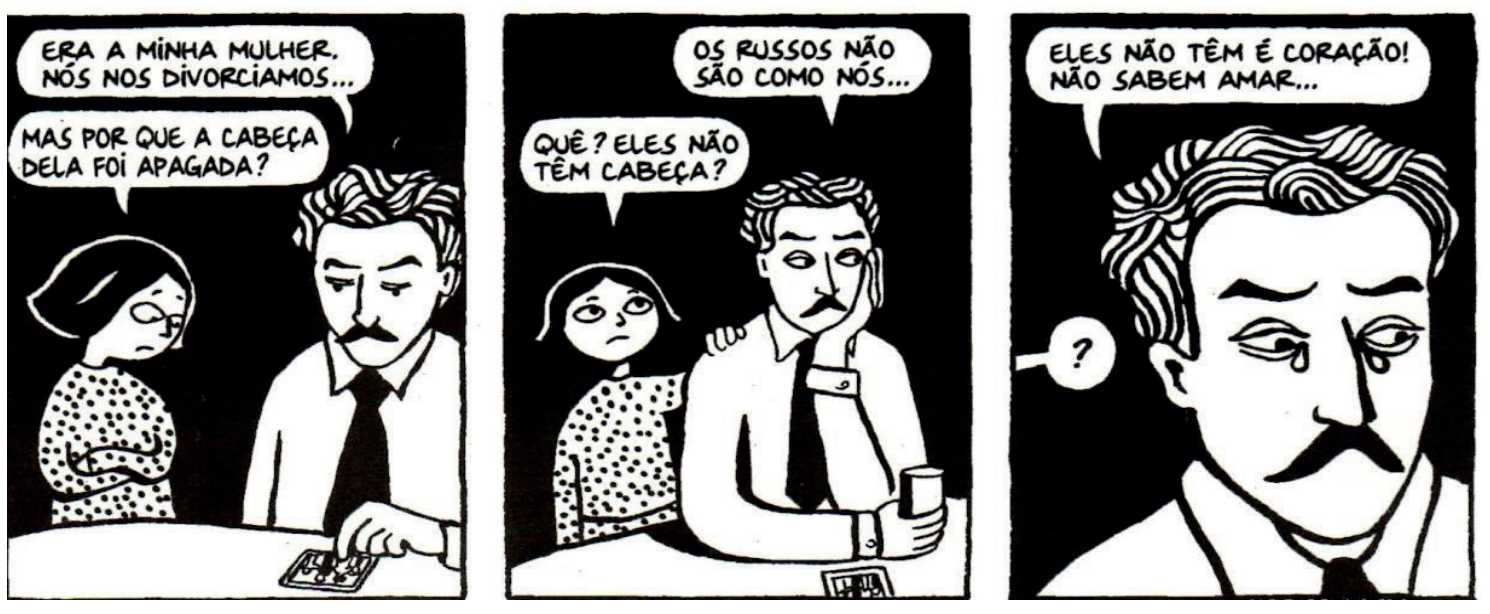

\section{CONSIDERAÇÕES FINAIS SOBRE A ANÁLISE DAS OCORRÊNCIAS DOS FENÔMENOS VARIÁVEIS DO PORTUGUÊS BRASILEIRO}

A presente pesquisa explicitou, de maneira teórica e comparativa, as características da tradução de quadrinhos e as ocorrências de normas linguísticas e oralidade fingida em um texto traduzido do francês para o português brasileiro.

As normas linguísticas influenciam o resultado de um texto traduzido, na medida em que ficam perceptíveis as suas representações híbridas nos quadrinhos pela sua 
linguagem e especialmente por causa da oralidade fingida.

A afirmação inicial de que nossa análise tem como base o $\mathrm{PB}$, tornou possível a conclusão de que, por razões editoriais e por causa do terceiro código presentes nas traduções, o tradutor Paulo Werneck empregou, em seu texto traduzido, aspectos normativos do PB descritos em Bagno (2012b).

Com a análise de Persépolis foi possível identificar, atentando para as ocorrências de fatos gramaticais, que Paulo Werneck também privilegiou as normas características do português brasileiro contemporâneo dentro da variedade de prestígio urbana, conforme a descrição que dela fazem os compêndios gramaticais mais recentes publicados no Brasil. Essa opção pelo português brasileiro urbano contemporâneo se evidencia, quantitativamente, nos resultados obtidos na coleta e análise dos fenômenos variáveis do PB analisados, conforme o quadro abaixo:

Tabela 11: resumo das ocorrências de marcas e variações gramaticais

\begin{tabular}{|c|c|c|c|c|c|c|c|c|c|c|}
\hline \multicolumn{2}{|c|}{$\begin{array}{l}\text { DEMONS- } \\
\text { TRATIVOS }\end{array}$} & \multicolumn{2}{|c|}{$\begin{array}{l}\text { IMPERATIVO } \\
\text { (VOCÊ) }\end{array}$} & \multicolumn{3}{|c|}{$\begin{array}{l}\text { RELAÇÕES } \\
\text { PRONOMINAIS }\end{array}$} & \multicolumn{2}{|c|}{ TER/HAVER } & \multicolumn{2}{|c|}{$\begin{array}{l}\text { NÓS/A } \\
\text { GENTE }\end{array}$} \\
\hline \multicolumn{2}{|c|}{ Ocorrências } & \multicolumn{2}{|c|}{ Ocorrências } & \multicolumn{3}{|c|}{ Ocorrências } & \multicolumn{2}{|c|}{ Ocorrências } & \multicolumn{2}{|c|}{ Ocorrências } \\
\hline \multicolumn{2}{|c|}{233} & \multicolumn{2}{|c|}{134} & \multicolumn{3}{|c|}{94} & \multicolumn{2}{|c|}{78} & \multicolumn{2}{|c|}{225} \\
\hline- -ss- & - st- & indi- & subj- & $\begin{array}{c}\text { você/ } \\
\text { te }\end{array}$ & $\begin{array}{c}\text { você/ } \\
\text { o/a }\end{array}$ & $\begin{array}{l}\text { você/ } \\
\text { lhe }\end{array}$ & ter & haver & nós & $\begin{array}{c}\text { a } \\
\text { gente }\end{array}$ \\
\hline $84 \%$ & $16 \%$ & $78 \%$ & $22 \%$ & $90 \%$ & $10 \%$ & - & $62 \%$ & $38 \%$ & $51 \%$ & $49 \%$ \\
\hline 196 & 37 & 105 & 29 & 85 & 9 & - & 49 & 29 & 115 & 110 \\
\hline
\end{tabular}

Fonte: Os autores.

O português brasileiro (PB) vem sendo estudado como uma língua autônoma, com características próprias e normas empiricamente comprovadas. Muitas normas reais do PB diferem das normas codificadas da tradição normativa porque nos estudos científicos sobre a língua majoritária do Brasil são considerados os aspectos genuínos da fala dos brasileiros.

A premissa principal dessa pesquisa era de que as normas linguísticas incidentes no texto, por meio das escolhas do tradutor e também dos agentes normatizantes, assim como os traços de oralidade fingida, são fatores que influenciam no texto final. Além disso, a própria estrutura da linguagem dos quadrinhos e suas características, que vão desde a linguagem icônica até os recursos gráficos específicos, demonstram que o trabalho do 
tradutor dessas histórias não se restringe ao texto escrito nos balões e nos cartuchos. A oralidade fingida presente nos quadrinhos também colabora para a análise de um idioma genuíno, já que, mesmo que não premeditada, a intenção é mostrar o uso da língua em seu nicho mais natural: o diálogo.

Portanto, um gênero como os quadrinhos, em que a relação entre língua falada e língua escrita é pautada em suas semelhanças e não por suas diferenças, é um suporte ideal para a confirmação de que, para uma descrição honesta das regras do PB, é preciso considerar a fala daqueles que usam o idioma cotidianamente.

Desse modo, os resultados obtidos após a análise nos levaram a concluir que o texto final traduzido de quadrinhos sofre influência dos traços de oralidade fingida presentes no texto fonte e que as variedades de normas linguísticas constituem um fator determinante no resultado final desse texto, já que o tradutor, consciente ou inconscientemente, deixa incidir sobre ele suas marcas de norma e, para a publicação, os agentes normatizantes também decidem sobre as opções normativas por eles consideradas aceitáveis para o mercado editorial.

A tradução é considerada por muitos um ofício e tem uma função social importante. Nesse sentido, a pesquisa sobre os mecanismos de tradução de um gênero de texto específico pretende contribuir para a definição e fixação dos estudos da tradução como área de conhecimento específico, a tradutologia. 


\section{REFERÊNCIAS:}

ANSELMO, Z. A. Histórias em quadrinhos. São Paulo: Vozes, 1975.

BAGNO, M. Norma linguística, hibridismo \& tradução. 2012a. Revista Traduzires, Brasília-DF: UnB, n.1, p.20-32.

BAGNO, M. Gramática pedagógica do português brasileiro. 2012b. São Paulo: Parábola, $450 \mathrm{p}$.

BAGNO, M. A norma oculta. 2003, São Paulo: Parábola, 98 p.

BAGNO, M. (org.). Linguística da norma. 2002. São Paulo: Loyola, 102 p.

BAGNO, M. (org.). Norma linguística. 2001. São Paulo: Loyola, 145 p.

BAKER, M. Reexplorer la langue de la traduction: une approche par corpus. França: Meta, 1988.

BARBOSA, A. et al. Como usar as histórias em quadrinhos na sala de aula. São Paulo, Contexto, 2004.

BECHARA, E. Moderna gramática portuguesa. Rio de Janeiro: Lucerna, 1994.

BRAGA, A. C. Norma linguística e oralidade fingida na tradução de Persépolis, Dissertação de Mestrado em Tradução. Universidade de Brasília, 107 p, 2013.

BRAGA, F. PATATI, C. Almanaque em quadrinhos 100 anos de uma midia popular. Rio de Janeiro: Ediouro, 2006.

BRUMME, J. (Org.). La oralidad fingida. Descripción y tradducción.Teatro, cómic y médios audiovisuales. Madrid: Iboamericana/Veuvuert, 2008.

CIRNE, M. Quadrinhos, sedução e paixão. Rio de Janeiro: Editora Vozes, 2000.

EISNER, W. Quadrinhos e arte sequencial. São Paulo: Martins Fontes, 1995.

FARACO, C. A. Norma Culta brasileira: desatando alguns nós. São Paulo: Parábola, 2. ed., 2009.

GUERINI, A.; BARBOSA, V. (Orgs.) Pescando imagens com rede textual: HQ como tradução. São Paulo: Perópolis, 2013. 
MESCHONNIC, H. Traduire: écrire ou désécrire. Scientia Traductionis, n.7, 2010.

MESCHONNIC, H. Poética do traduzir. Tradução: Jerusa Pires Ferreira e Suely Fenerich. São Paulo: Perspectiva, 2012.

RAMOS, P. A leitura dos quadrinhos 2.ed.São Paulo: Contexto, 2012.

SANTAELA, L. O papel da iconicidade da língua na literatura. Belo Horizonte: Scripta v.7, n. 14, p.128-136, 2004

SATRAPI, M. Persepolis. França: L'Association, 2007.

SATRAPI, M. Persépolis Completo. São Paulo: CIA das Letras, 2011.

SHAFFNER, C. The Concept of Norms in Translation Studies. Institute for the Study of Language and Society, Aston University: Birmingham, UK, 1998.

SINNER, C. Variación, representatión del contato linguístico y oralidad fingida em los Baldrich de Us Lahoz. In Jenny Brumme / Anna Espunya (org): The translation of fictive dialogue. New York: Rodopi, p.436-437, 2009. 